\title{
The Influence of German Siedlungen and Bauhaus on Helsinki's Prewar Housing Companies
}

Juhana Heikonen

This article sheds light on the Bauhaus movement and other types of German influence on 1930s housing companies in Helsinki by reassessing their reception by the Finnish architectural press at the time. ${ }^{1}$ Unlike public sanatoriums, schools, libraries, and so forth, the housing companies were formed autonomously without control from above. Functionalism, as the Finnish interwar architecture is called, had reportedly arrived from Sweden through the close contacts between Finnish and Swedish architects. The main channels of influence were the joint Nordic conferences and other types of cooperation. ${ }^{2}$ However, there is little direct proof of this transmission, and most such proof is circumstantial. This paper evaluates both circumstantial and architectural evidence regarding German influence in the interwar period. Even though the scope of the Bauhaus movement and German influence is broad, ranging from town planning to spatial arrangement, the focus is on a single decade, a single building type, in a single city.

The greatest achievement of the Bauhaus movement in terms of volume was the new approach to affordable housing. However, the Bauhaus movement itself resulted in only a small number of architectural works, except for architect Walter Gropius' (18831969) own architectural practice with his students. The main volume of new buildings was the work of such architects as Ernst May (1886-1970), Bruno Taut (1880-1938), Martin Wagner (1885-1957), Hans Scharoun (1893-1972), and Hugo Häring (18821958). Both teachers and students were involved during the 1920 s and 1930s in new large-scale housing projects in Frankfurt, Berlin, and other German cities, as originally required by the new Weimar constitution of 1919, which attempted to tackle the housing crisis via new financing models. These new Siedlungen (subsidized housing estates) were made possible by the earlier models of Baugenossenschaften, or housing cooperatives. $^{3}$ which acted as the main contractors and owners of the property and were partially subsidized by the city or the state. This form of cooperative building was naturally in line with Walter Gropius' 1919 manifesto and based on cooperation between different parties.

The Finnish Joint-Stock Housing Companies, or Asunto-osakeyhtiö (Bostadsaktiebolaget)

The city of Helsinki did not have the resources to subsidize any kind of housing,

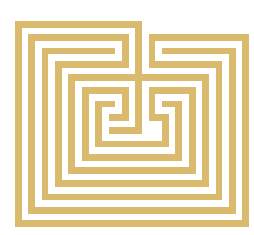


and thus, the housing crisis was dire. However, the Finnish 1926 Asunto-osakeyhtiölaki, which replaced the 1895 Limited Liability Companies Act previously used to form jointly owned real estate ventures was partially developed for this purpose: to help build, finance, and maintain jointly owned real estate properties. ${ }^{4}$ In short, a housing company is a normal joint-stock company that enables the stockowner (in many cases the owner-occupier, the thus habits and the apartment corresponding the stock) to own a specific flat. This new system enabled both the stockowner and the company to borrow money and finance the operation. This also enabled lending banks short on capital to borrow from abroad. Founding a company was a surprisingly effective way to battle the housing shortage, and it was also favored by the mainly social democratic cooperatives, which functioned as umbrella organizations for their members. The law proved to be a success both in increasing housing production and competition.

The Finnish Asunto-osakeyhtiö is a similar housing arrangement as with various type of American condominiums, Wohnungseigentürmergemeinschaften, ${ }^{5}$ and so forth.
However, since the Finnish arrangement is legally a joint stock company, the history of mass housing in Finland differs from the rest of Europe. The housing company is based on private home ownership, comparable to real estate ownership, and therefore it should not be confused with various forms of tenant housing, although the stockowner is fully capable of renting out the apartment. In practice, this means that jointly shared real estate properties are built, traded, and administered as a joint stock housing compa$n y .{ }^{6}$ Compared to the widespread Swedish bostadsrätt system (Dauerwohnrecht, right for long term rent), which is as a system more closely resembling German models, the Finnish model was based on self-organizing and was more independent. Since the developers differed for each house, the houses also architecturally differed from one another based on personal preferences and were not part of some centrally organized greater entity (as in Germany).

The founders of these companies varied greatly. The majority were normal developers who built to sell. Those in the minority included the state, cities, Finnish co-ops and various ad hoc groups, such as railroad workers, bankers, professors, or officers. They hired their own supervisors, builders, and other experts, and, as can be expected, oversaw the work of the architect as well. In all cases, the city of Helsinki provided the town plan and sold or rented the land.

\section{Foreign Influences}

The earliest and still one of the best accounts of Helsinki's prewar housing situation has been written by architect Hilding Ekelund, Helsingin kaupungin historia (1962). ${ }^{7}$ In Ekelund's view, the prewar influences came first from Sweden, Denmark, and Italy and then later Germany. According to Ekelund, Finnish functionalism was influenced by the 1930 Stockholm exhibition, but the influence had been greatly overestimated in later research. ${ }^{8}$ The production and design of Helsinki's housing companies, and the professional press of the time, support Ekelund's claim.

Later studies have placed more importance on Nordic co-operation but offer no decisive conclusion as to which source was the most important since the new influences were brought to Finland by individual architects. The Swedish influence has been em- 
phasized by Riitta Nikula and Pekka Helin as well as Petri Neuvonen in the updated reprint of the history of apartment buildings from 1880 to $2000 .{ }^{9}$ According to Raija-Liisa Heinonen, the new wave was driven primarily by architects Alvar Aalto (1886-1976), Erik Bryggman (1891-1955), and Pauli E. Blomstedt (1900-1935), followed by Hilding Ekelund (1893-1984), Erkki Huttunen (1901-1956), and Yrjö Lindegren (19001952). These architects stood somehow in opposition to, according to Heinonen, the old guard of Sigurd Frosterus (1876-1956), Armas Lindgren (1874-1929), J. S. Sirén (1889-1961), Eliel Saarinen (1873-1950), and Lars Sonck (1870-1956). While Heinonen's seminal work on Finland's early functionalism does not concentrate on the influence of German Siedlungen or the Bauhaus movement as such, it also finds the German influence especially important with respect to town planning and public buildings. ${ }^{10}$ Hence, the present article concentrates on a different group of architects and genre than previous research. Architect Kirmo Mikkola (1934-1986), in Transition from classicism to functionalism in Scandinavia (1985), has summarized the Nordic influence as fol- lows: it was vital for 1920 s classicism, which gave birth to functionalism. ${ }^{11}$ Even though this transition included both public buildings and housing in the Nordic countries, Finnish housing took a slightly different route to functionalism due to private funding.

Research on German Siedlungen, or Bauhaus influence, has mostly focused on the Congrès internationaux d'architecture moderne, or International Congresses of Modern Architecture (CIAM), on building fairs, or in some cases, on direct person-to-person influence, like in the case of Aino (1894-1949) and Alvar Aalto. Recent important studies include the Bröhan Museum's exhibition publication Nordic Design. Die Antwort aufs Bauhaus. ${ }^{12}$ However, this publication does not focus on housing except for briefly mentioning Aalto's two housing companies in Turku (1929). Regarding German influence in general, Atli Seelow argues that German influence was crucial in the development of 1930s Swedish architecture. Seelow also suggests that functionalism arrived in Finland through the work of Swedish architect Sven Markelius (1889-1972). ${ }^{13}$ Markelius certainly had influence, but his own contributions to housing were modest, namely in the form of Berget 10 (1930) and Kollektivhuset (1935) in Stockholm. These projects do not bear much architectural similarities to Finnish examples.

The general research literature on housing companies in Finland includes Kerrostalo 1880-1940, Kansanosake - Suomalaisen asunto-osakeyhtiön vaiheet, and Arkkitehtuurimme vuosikymmenet 1930-1950. ${ }^{14}$ The most comprehensive architectural study on housing companies in Helsinki is Tommi Lindh's Töölöläisfunktionalismin 4 vaihetta. The study concentrates both on changing urban planning practices, the developers, and the lesser-known architects responsible for the new functionalist housing architecture. Lindh finds Hamburg's new Siedlung architecture the most comparable to Helsinki's functionalist architecture. ${ }^{15}$

In Finland, architectural style and thinking changed swiftly from Nordic Classicism to functionalism at the end of the 1920s and early 1930 s. Even though it is nearly impossible to pinpoint how or why such a turn occurred, it has been quite generally thought that most of the influence came through the close collaboration among Nordic architects, such as Finnish architects Alvar Aalto, Erik Brygg- 
man, and Hilding Ekelund collaborating with their Swedish counterparts Sven Markelius and Gunnar Asplund (1885-1940). Indeed, the ties were close especially because of the common language they all used - Swedish. However, there is also a different line of enquiry that concerns Finnish architects traveling to Germany and the resulting close collaboration, such as in the case of Alvar Aalto and Aarne Ervi (1910-1977).

The building and architectural press was mainly interested in trends in the U.S., the Netherlands, Denmark, Sweden, and Germany. On the quantitative level, the Dutch and the Germans were quick to build much new modern housing, unlike the Danes, Swedes, or even the French. Did architects travel to see the new types of architecture, then? Yes, they did, and Germany would have been the first choice for most. Beginning in 1914, the new steamship Ariadne took travelers from Helsinki to Stettin in just two days on a weekly basis. The focus of this article is on Bauhaus architects such as Walter Gropius and Ernst Neufert (1900-1986), their work, and their possible influence on Finnish housing company architecture through an assessment of the Finnish architectural press and how it was stylistically or methodologically influenced by the Bauhaus movement.

\section{The Developers}

Even though the construction activity of housing companies in Helsinki was first popular among the owner-occupiers and related investors, professional developers and master builders came along at the beginning of the 1920s. One of the most productive was master builder Leuto A. Pajunen (1888-1950), who built and founded especially so-called communal kitchen housing companies, where even the largest apartments rarely had fully equipped kitchens. This was not due to Soviet-inspired constructivist housing with similar arrangements, but instead, due to post-war inflation and a lack of means to afford private services. Food was prepared in the communal kitchens and sent to the apartments via service elevators. Pajunen built these communal kitchen houses between 1920 and 1927. The journal Rakennustaito later remarked on Sven Markelius' collective house (Kollektivhuset) in Stockholm by saying that Pajunen had already done the same, but it was never successful. ${ }^{16}$ Architects Elna Kiljander (1889-1970) and Gustaf Strengel
(1878-1937) were more positive in their reviews due to far better other communal services in Kollektivhuset. ${ }^{17}$

In the 1930s, many professional developers and master builders started to unite and take charge of constructing and founding the housing companies. Before the 1929 financial crash, the more adventurous developers had caused many bankruptcies and a lot of negative publicity. For this reason, and for security reasons with respect to future stockholders, many developments were arranged among trusted friends, colleagues, or trade union members. Some of the professional developers and master builders returned and, for example, in Pajunen's case they did so with a modern touch. The change from stripped-down classical architecture to functionalism is noticeable, since $\mathrm{Pa}$ junen's own designs were widely considered of poor quality, with overly large frame depths, dark hallways, and unpractical plans. In a joint project with his colleague Uno Lehtinen (1934), differences in quality could still be observed between the neighboring houses, since Lehtinen hired architect Helge Lundström to design his own half of the joint project. ${ }^{18}$ 

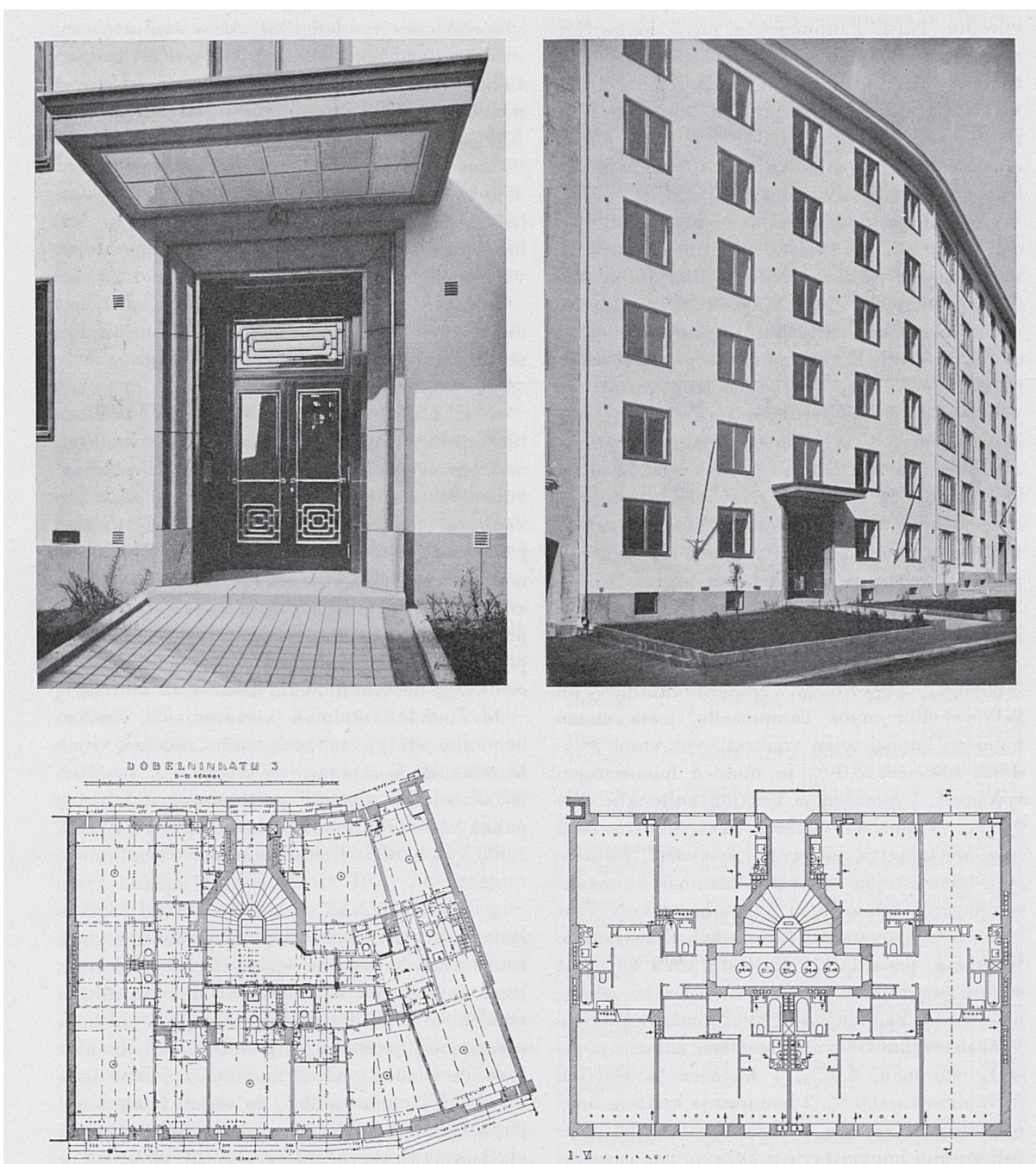

Until the 1929 financial crisis, most of Helsinki's housing company developers and founders were owner-occupiers. By the time building activities resumed in 1934, this had changed to the economic benefit of commercial developers. This naturally caused a great uproar among the general public, and new nonprofit developers, such as HAKA, SATO, Asuntoemissio Oy, and Asuntohankinta Oy, were founded to meet the needs of lower income families. ${ }^{19}$ This was also due to Social Democratic Party winning the Conservative Party in Helsinki's communal elections (1930-1945). Co-operatives like HOK and Elanto had also been quite active in building small-scale housing companies for their members, which were purchased in installments or via direct housing company loans. The early adoption of functionalist design can also be seen in these projects.

Of the developers working at the time, Lauri and Lasse Reitz especially promoted functionalist architecture by architect Jalmari Peltonen (1893-1969), who designed major-

Figure 1. As. Oy Helsingin Döbelninkatu 3 (street view and plan on left side, Leuto A. Pajunen, 1934) and As. Oy Döbelninkatu 1 (street view and plan on right, Helge Lundström, 1934) show the preferences of two different designers, even though the façades are near identical except for the pompous marquee in Pajunen's design. Rakennustaito, no. 19 (15.9.1934): 19-20. 


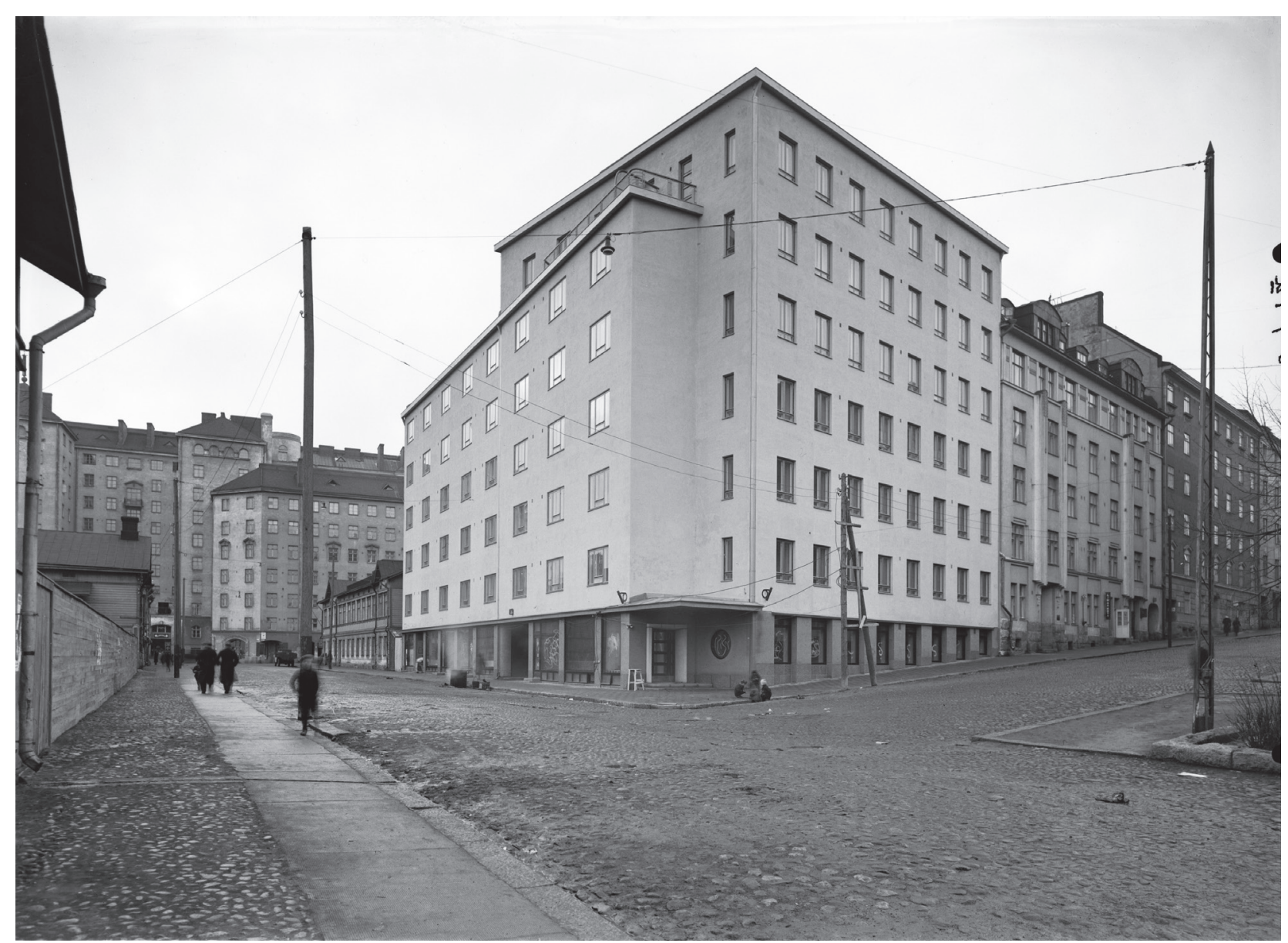

Figure 2. As. Oy Pääskylänrinne (Georg Jägerroos and Antero Pernaja, 1933), built by the HOK-Elanto cooperative. HOK-Elanto built several housing companies for their members during the 1930s. One of the common features of these companies was Elanto groceries, or other cooperatives services, such as restaurants. Helsinki City Museum. 
ity of their projects..$^{20}$ Jalmari Peltonen's most famous housing company was most probably As. Oy ${ }^{21}$ Etelä-Hesperiankatu 22, which was built for Lauri Reitz personally and is still owned by the foundation he created. One of its distinctive characteristics is the famous restaurant Elite, designed by designer Werner West (1890-1959) and realized by Stockmann/Keravan Puusepänteollisuus Oy. Another good example is As. Oy Topeliuksenkatu 1, by Reitz and Peltonen. The monumental stairwells of this corner house are in the style of Weiße Stadt in Berlin. ${ }^{22}$ However, Reitz did not share the modern German idea of creating small frame depths for reasons of cost effectiveness. ${ }^{23}$ This marks one of the main differences between the Finnish and the German developers. ${ }^{24}$ Though Finnish architects mostly agreed publicly with the Germans, they did not always follow the German example in their work.

The main problem when discussing functionalist, or Siedlung, influence on the housing companies in Helsinki had to do with the adoption of new architectural ideas into an older grid town plan. In Germany, or Sweden, most modern architecture was built carte blanche on no previously existing town plan. This would change after the Meilahti district master plan was approved in Helsinki 1939. In most cases, the influences of the developers and architects can be seen in the apartment plans, façade detailing, and construction technology. The Siedlung would be fully adopted after the war.

\section{The Nordic Building Forums and Oth- er European Fairs}

Nordic building forums were organized in Stockholm (1927), Helsinki (1932), and Oslo (1938). They have been considered very important for the exchange of ideas and architectural development in Finland. Other major Swedish building fairs have also been considered crucial for the turn in the 1920s from Nordic Classicism to functionalism. ${ }^{25}$ Especially the Stockholm Exhibition (1930) showcased functionalistic architecture in the Nordic countries and was inspired by Stuttgart's Weissenhofsiedlung (1927). Though such influence cannot be disputed, it is important to remember that at this point functionalist architecture in the Nordic countries was still quite limited, or almost non-existent. The exhibitions did not showcase new housing as such. CIAM was another influential and widely publicized disseminator of ideas, but Alvar Aalto was the only Finnish member of the organization.

Alvar and Aino Aalto had personal contacts with those in the Bauhaus movement and within CIAM circles. Alvar Aalto visited the Nordic building forums and new German Siedlungen estates and participated as the sole Finnish architect at the 1929 Frankfurt congress. ${ }^{26} \mathrm{~A}$ particular Finnish architectural highlight of 1929 was the 700-year anniversary of the city of Turku. The journal Arkkitehti devoted its June edition solely to it. The fairground pavilions, designed by Alvar Aalto and Erik Bryggman, were laid out like a German Siedlung housing estate and the kiosks were clearly modeled according to German and Dutch examples with overlapping graphics. ${ }^{27}$

In 1930, a minimum apartment exhibition (Pienasunnon rationalisointinäyttely) was arranged in Helsinki Kunsthalle. The main curators were Alvar Aalto and P. E. Blomstedt. ${ }^{28}$ In this exhibition, Aino Aalto's first standard kitchen was also on display. The Nordic Building Forum of 1932 in Helsinki was far larger and considered a success. One of the highlights was the lamella competition, and 


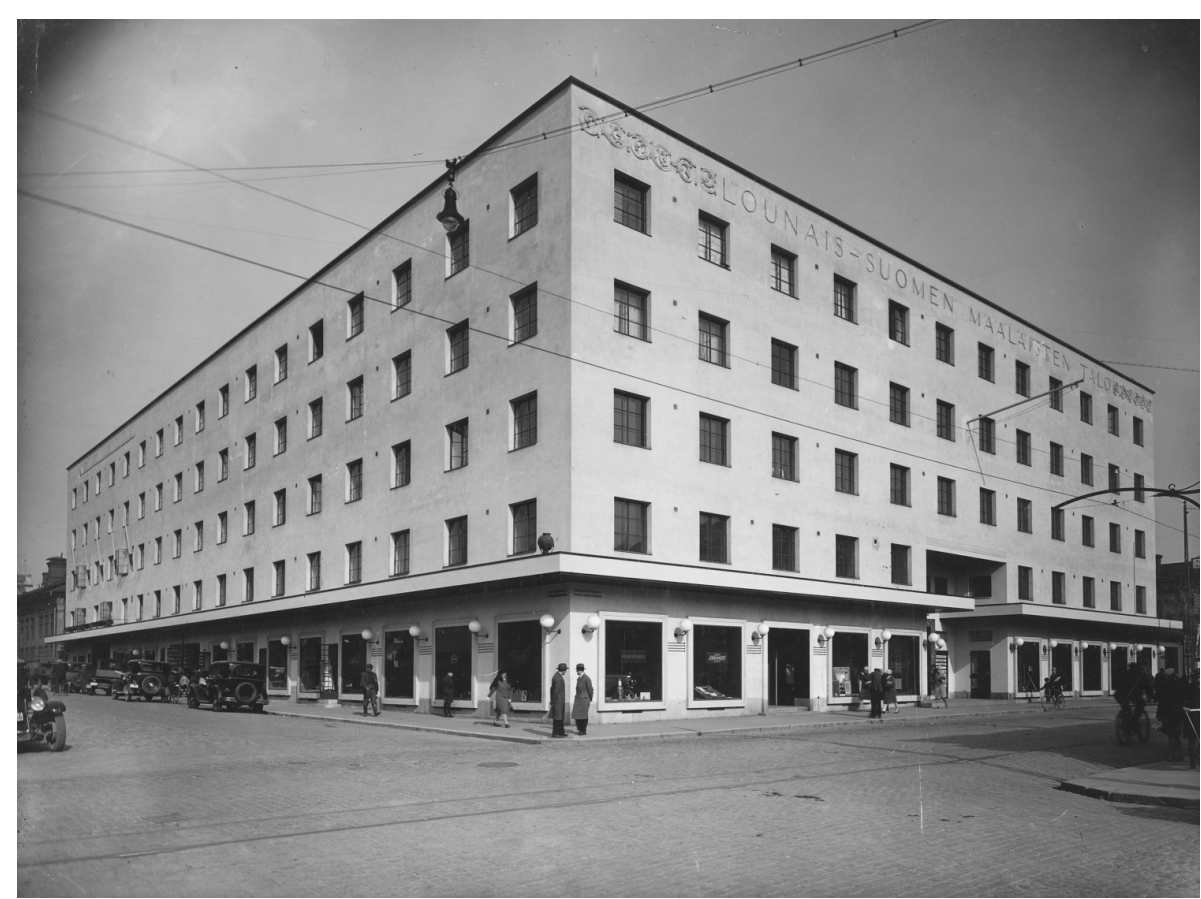

Figure 3. Southwest Finland Agricultural Cooperative Building, Turku, Alvar Aalto, 1928. Photo: Gustaf Welin, Museum of Finnish Architecture.

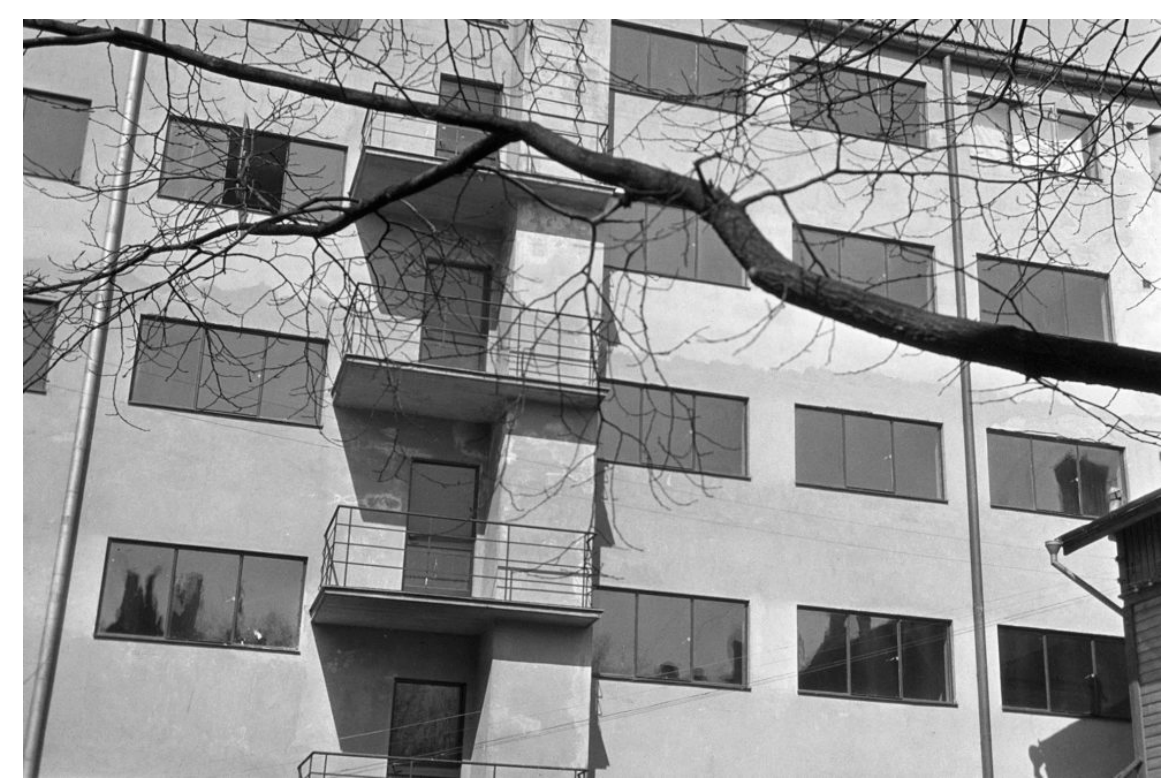

Figure 4. Standard Tenement House, Turku, Alvar Aalto, 1929. Photo: Aino Aalto, Museum of Finnish Architecture. which showcased the cutting edge of modern housing architecture and master planning. Contributors included P. E. Blomstedt, Ekelund, Bryggman, and Kaarlo Borg. ${ }^{29}$ At least for the Finnish architects, the long and thin lamellas of the competition would already have been familiar from German architectural publications on the new Siedlungen housing estates and Deutsche Bauaustel- lung (1931) or from the Weißenhofsiedlung lamella itself (Mies van der Rohe, 1927).

The subsequent 1934 Standard exhibition in Stockholm received a crushing review from Hilding Ekelund. ${ }^{30}$ All in all, most of the architectural press seemed more interested in Sweden's far better and more numerous public housing estates and their efficiency. This can be read in several accounts from
Finnish housing congresses organized at the time to tackle the housing shortage both in cities and the countryside. ${ }^{31}$ Even though the Finnish architectural publications' focus on foreign projects was limited, except for travel reports, the near absence of a focus on Swedish projects is remarkable. Even though Sweden hopped onto the Siedlung housing estate bandwagon in the mid-1930s, archi- 
tect Arvid Stille's (1888-1970) impressive Gärdet in Stockholm was only mentioned in passing in Byggaren (7/1934), or else anonymously mentioned by Hilding Ekelund in the context of the Etu-Reijola town plan.

What received wider publicity in the Finnish press was the Deutsche Bauausstellung in Berlin (1931). Arkkitehti published only Finnish architects' own impressions of the fair. Architect Harald Andersin (1883-1936) was overwhelmed by the fair's quality, but architect Birger Brunila (1882-1979) was dismayed by the fact that Finland was almost the only Nordic country to have a proper exhibition. Hilding Ekelund was not impressed by Mies van der Rohe's or Marcel Breuer's apartment designs and considered them unpractical and even cold. However, Walter Gropius' apartment tower design received much praise, and Ekelund saw strong prospects in it. Ekelund's finishing remarks parodied Germany's current architectural taste, ranging between the traditionalist right wing and the modernist left wing, with Ekelund in favor of the latter. Architect Martti Välikangas (1893-1973) concentrated on the technical and material exhibitions and their value for the forthcoming Nordic Building Forum in
Helsinki since he was also one of the curators of the forum. Välikangas wrote a longer report on the Deutsche Bauausstellung in Rakennustaito. ${ }^{32}$ In this more technical report, he concentrated on housing production costs in Berlin and how much better they had been arranged than in Helsinki.

\section{Traveling Architects and the Press}

The Grand Tour of Italy by Nordic architects has been widely considered crucial for the development of post-WWI architecture. The long tradition of traveling through Germany to Italy was seen an important part of completing an architect's education, and most Nordic architects at the time traveled to those countries. They included Alvar and Aino Aalto, Erik Bryggman, Hilding Ekelund, and Eva Kuhlefeldt-Ekelund (1892-1984). These tours produced some fine architecture along with hundreds of sketches depicting Italian architettura minora, later to be adapted for churches, schools, and apartment buildings throughout Finland. If Italian influence was self-evident for architects, why not then study modern German architecture on the way to Italy? One of the reasons may be that in general architects never sketched contemporary architecture, although it was recorded with cameras, especially by Aino Aalto and Eva Kuhlefeldt-Ekelund. One of the other reasons could also have been that new German architecture was immediately published and distributed worldwide.

Gustaf Strengel, the widely traveled architect and promoter of modern lifestyle choices, wrote already in 1931 in Uusi Suomi about "The New Europe: 'Siedlung' - The New German Housing and Settlement Type." Strengell carefully explained the Siedlung concept to a wider readership, as well as why the free-standing lamella house was better and why they should be built. The lengthy illustrated article included pictures of Neues Frankfurt and Schütte-Lihotzky's Frankfurter Kitchen. The article mentioned all the common architectural design traits of the period: allowing for more sunlight and air circulation. ${ }^{33}$ Architect Yrjö Laine continued with the same theme in Kotiliesi (Hearth), providing more German examples and showcasing the successes of the Lamella competition (1931). ${ }^{34}$

Of the several published architects' German travel reports, Eva Kuhlefeldt-Ekelund's report from 1931 is of special interest. Kuhle- 
feldt-Ekelund already found modern German housing highly impressive just by the staggering number of places being built. Her interest, unlike in other architects' reports, is landscape architecture, utility spaces, and services at the new Siedlungen housing estates in Berlin, Frankfurt, and Dessau. Gropius' Dessau-Törten did not impress Kuhlefeldt-Ekelund much since the gardens were less successful. ${ }^{35}$ This critical view was shared by architect Vietti Nykänen, who visited Dessau-Törten in 1928. Nykänen favored classical architecture and never followed his colleagues in promoting functionalism. Although he was impressed by the floor plans, the pace of building, and the technological achievements, in his judgment the designs were monotonous and ugly. ${ }^{36}$ The article was fully illustrated with plans and sections for readers to form their own opinions. These views differed greatly from those of Sven Markelius, who celebrated Dessau-Törten in the Swedish press. ${ }^{37}$

It is safe to say that most of the architects had visited many of the new German Siedlungen housing estates and several of them the Bauhaus Dessau building as well, since it has become internationally famous almost overnight. ${ }^{38}$ After graduation, several Finnish architects either studied or worked in Germany. This was a logical choice due to the fact that the third language for Finns at the time, after Finnish and Swedish, was German or French. Many notable architects had worked in German offices, such as Selim A. Lindqvist (1867-1939) at the office of August Menke in Berlin. In general, in the early twentieth century the most favored places for students of architecture to complete their studies or work were Stockholm, Munich, Berlin, and Vienna. ${ }^{39}$ A later Finnish functionalist architect who studied in Germany was Gösta Juslén (1887-1939), who also was well acquainted with Bauhaus and will be discussed later in the article.

The Finnish press was also highly interested in everything German at that time. The press wrote about architects, such as Alvar Aalto's and Erik Bryggman's trips to Dessau, Stuttgart, Berlin, and Hamburg..$^{40}$ More important, probably, was the professional press, namely Arkkitehti/Arkitekten, Rakennustaito, Byggmästaren, and Teknikern. These journals from early on wrote about German developments and about various building conferences and seminars. Also,
German architecture literature and pieces by the professional press were equally presented along with writings from the Swedish, American, and British press. The professional press also covered these subjects in their travel reports.

There was also much interest in new construction methods. The journal Rakennustaito was the most active publisher on this subject, and most of the articles concentrated on the U.S. and Germany. This was due to the new emphasis on the standardization of building parts, such as windows ${ }^{41}$ or new building blocks. ${ }^{42}$ The latter topic focused especially on the new technology used in Ernst May's Neues Frankfurt and Walter Gropius' Dessau-Törten.

Walter Gropius was closely followed in Finnish circles, and the German building program was of great interest, as evident from the Finnish professional press's numerous book and journal reviews. ${ }^{43}$ It would be misleading to say that only architects wholeheartedly adopted German ideas. Building designs also concerned clients and engineers, who began to take charge of the housing industry at the time. The influence of the Bauhaus movement did though begin to 
generate interest among construction engineers as well. Paavo Kyrenius (1885-1955), a construction engineer, wrote an article based on Gropius' lecture in Stockholm, saying that he completely agreed with Gropius' grand plans for ten-story apartment blocks and related ideas regarding land policy, the shape of the apartment blocks, master planning, financing, new building materials, and labor force organization and administration. Kyrenius' view was that the efficient concrete high-rise apartment blocks would produce better living than current Finnish town planning. ${ }^{44}$ In Helsinki, these types of apartment blocks were constructed after the war.

The Bauhaus publications were also closely followed, which may also have had an influence on Arkkitehti's own layout renewal in the early 1930s. In the August issue of 1935, the editorial board of Arkkitehti even made a strong recommendation to use designer Paul Renner's (1878-1956) Futura design in the architectural material submitted for the journal. ${ }^{45}$

\section{The Aaltos and Bauhaus}

Alvar Aalto is discussed separately here since he did not design a single housing com- pany in Helsinki before the war but still had great influence both at home and abroad. Alvar Aalto had the closest relationship with those in the core of Bauhaus movement, namely through Gropius and artist László Moholy-Nagy (1895-1946). The latter also visited Finland in 1931 and gave an enthusiastic interview on Finnish architecture to the newspaper Turun Sanomat. ${ }^{46}$ The article concentrated more on Siegfried Giedion's appraisal of Alvar Aalto. Moholy-Nagy also directly influenced Aino Aalto's photographic experiments, which can be seen in pictures of the Aaltos' early work. ${ }^{47}$ Alvar Aalto's close friend, client, and biographer, Göran Schildt (1917-2009), wrote several other books and articles specifically on Alvar Aalto's relationship with those in the Bauhaus movement. Alvar Aalto never admitted any Bauhaus influence in his work, but his biographer did not believe him and went to great lengths to prove Aalto wrong on the matter. ${ }^{48}$ Following Alvar Aalto's early work, similarities can be drawn with Hugo Häring's work. ${ }^{49}$ Arkkitehti also reviewed the work of Häring, Mies van der Rohe, and others as well as books by Ludwig Hilberseimer and Gropius, so Alvar Aalto must have been acquainted with their projects.
Interior design also received more attention in the press during the interwar years. Reviews of new Bauhaus steel furniture, textiles, cutlery, and pottery were not published, except in the case of Aino Aalto's interior design for the Maalaistentalo apartment building. ${ }^{50}$ The 1929 issue of Arkkitehti also discussed two housing projects by Aino and Alvar Aalto in more detail: Maalaistentalo as well as "The Standard Tenement Building." The former was a more traditional and classical corner building with restaurants, a theatre, and other services for members of the co-operative that built it, with all the upper floors divided into apartments and partially decorated by Aino Aalto for the Turku fair with her own designs, Thonet furniture, and Marcel Breuer's Wassily chairs. The latter building was also built by the same contractor, J. Tapani. This tenement building was, however, completely different, even though designed at the same time. Aside from local building regulations and specifications in the site plan itself, it was built as a "lamella" in the German style. It also had curtained walls and a load-bearing system typical of the newly prefabricated concrete floors, supported by prefabricated blocks between the 
apartments. These construction styles were already in use on an industrial scale in Germany but not in the Nordic countries. Both projects were completed by the time of the 1929 fair. Everything was marketed under the slogan standardization, a year before Markelius' Berget 10.51

One of the students of the Bauhaus movement, an assistant to Gropius on several projects, and later a professor of architecture, was Ernst Neufert. He became famous due to his revolutionary building manual Bauentwurfslehre (The Architects Data). Neufert knew Alvar Aalto personally and they visited each other at times. Neufert's first visit to Finland was in 1933, when he wanted to study the new bent plywood furniture for his forthcoming manual and to have detailed discussions on standardization. ${ }^{52}$ Alvar Aalto also later introduced Neufert to the younger Finnish architects. The first manual was immediately partially reproduced in Arkkitehti and received much praise. ${ }^{53}$ The first meeting between the two architects grew into a more state-level partnership during the war, since Finland sold module barracks to the German army and because, for PR reasons, Neufert visited Finland later in 1942 in the context of the Finnish Association of Architects' standardization project. ${ }^{54}$

The 1938 Nordic Building Forum in Oslo was one of the turning points in Alvar Aalto's career. After designing Villa Mairea, his own house, and several others, his speech called for a standardization based on nature that would not shackle the architect too much and would hopefully provide endless ways to combine different standards. Also, he made a plea that town planning should do the same. ${ }^{55}$ This represented a direct and conscious counteraction to the ideals of the Bauhaus movement.

\section{Urban Renewal}

Examples of the German-type Siedlung housing estates were built only occasionally in Finland before the war. The only exceptions in Helsinki were Puu-Käpylä housing (Birger Brunila, Otto-livari Meurman, Martti Välikangas and Akseli Toivonen, 1920s) and Olympiakylä (Martti Välikangas and Hilding Ekelund, 1938-40). The first one was a lowcost, partially prefabricated wooden garden suburb, representative of Nordic Classicism, while the latter already softened functionalist style in stone with saddle roofs. Both were financed and built by the city of Helsinki's own non-profit building company. The main reason for the lack of German-type Siedlungen housing estates was funding - the city of Helsinki did not have the money, and neither did any other city. Brunila also made several suggestions of plans for Reijola, Meilahti, and Kulosaari districts in the early 1930s, based on lamellas, but these plans were only partially adopted in Helsinki, which also owned most of the land. ${ }^{56}$ In 1940, Ekelund suggested improvements for Reijola, which were partially adopted. In comparison, Ekelund's plans clearly illustrated that the planning of housing should not be done separately from general planning and clearly show Gropius' influence from the 1931 Bauaustellung. ${ }^{57}$ This is one of the main differences compared to P. E. Blomstedt's attempts at town planning.

Hilding Ekelund attacked the slow development of housing by stating three problems that Helsinki was facing at the time: town plans, profit-seeking developers, and the architects themselves. ${ }^{58}$ The developers added to lamella's frame depth, and the city sold building plots in auctions, which in turn led to land speculation and higher prices. Ekelund's 


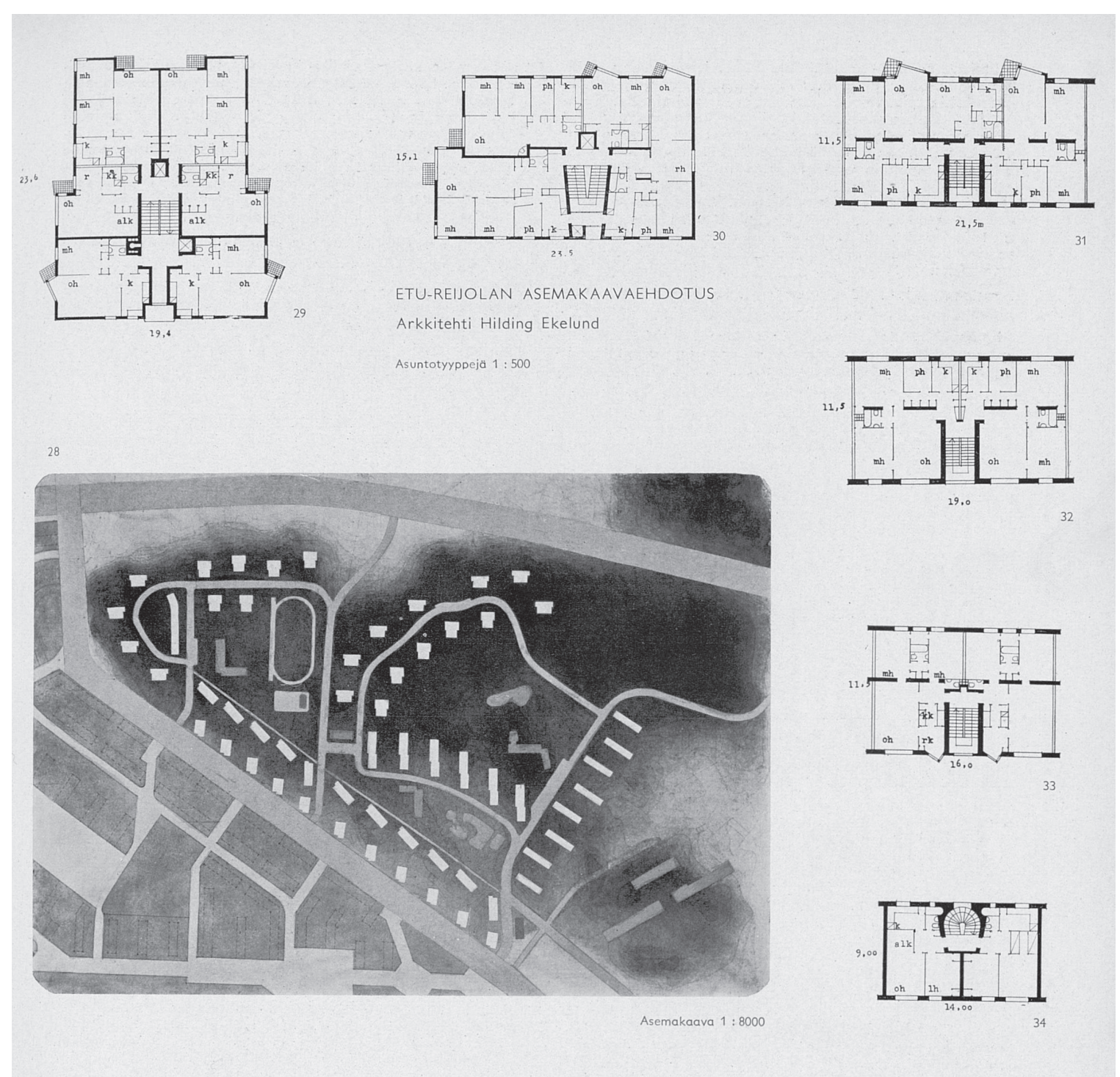

Figure 5. Hilding Ekelund's masterplan of Etu-Reijola and model apartments for lower income people, 1940. Arkkitehti 1.3.1941, no 3, p. 47. solution was to rent the land, which could then be more ideally planned, and to favor developers that were owner-occupiers, as was done before. For the architects, he suggested some professional pride.

Ekelund's answers to the problem of poor housing quality had included his two proposals for lamella competition at the 1932 Nordic Building Fair in Helsinki. The first one was a typical lamella block house, but the second proposal, that of large, semi-detached atrium housing in the "Roman" style, was unusual. ${ }^{59}$ Ekelund was quite familiar with the concept due to his travels in Pompei. Atrium houses only gained in popularity in the Nordic countries two decades later.

In the 1930s, the only other project in Helsinki region comparable to Puu-Käpylä and Olympiakylä was Alvar Aalto's Munkkiniemi plan, consisting of several lamellas a hundred meters long for the M. G. Stenius company, but it was never realized. One of the reasons was that Helsinki wanted to annex the M. G. Stenius company land for its own purposes, and to further this objective the city basically cut off the water supply to Munkkiniemi, which crippled the company. This meant that the town plans and housing ar- 
chitecture designs were made by different teams, a fact best illustrated in Taka-Töölö and Meilahti. ${ }^{60}$ Olympiakylä would remain the only German-type Siedlung housing estate in Helsinki before World War II. ${ }^{61}$ Even though Pauli E. Blomstedt did not design housing, he devised competitive plans for rearranging Siltaaari, Töölönlahti, and Norrmalm (Stockholm) in the early 1930s. ${ }^{62}$ The urban structure based on long lamellas is reminiscent of the German Siedlungen.

In 1939, Arkkitehti published a special edition (no. 5-6) to cover the late town planning development by Birger Brunila's team. Linnankoskenkatu, Meilahti, and Olympiakylä areas were well on their way, and several other developments, such as Lauttasaari (architect Ole Gripenberg), were on the drawing board. All the new town plans were based on lamella buildings, while the Lauttasaari plan also included ten-story apartment blocks. However, as mentioned before, these plans were not comparable to the German or even Swedish plans, since all the land was owned by the city of Helsinki and it was to be sold parcel by parcel to a multitude of developers and contractors. ${ }^{63}$

\section{The New Modern Apartments}

Design of the housing apartments changed during the 1920s. The overall size of the apartments became more uniform: middle class built their own housing companies, and the working class did the same with more modest apartments, usually consisting of a room and a kitchen. During the hard years of the early 1920s, the servants' stairs virtually disappeared since the middle classes could not anymore afford servants. The salon, dining room, and other specified representational spaces were adjoined as a living room.

In 1929, several cabinet and furniture manufacturers from city of Lahti sent a delegation to Germany to study three different carpentry schools to establish a new school in Lahti. Among the participants were interior designer Werner West and architect Gösta Juslén along with the director of the furniture company Keravan Puusepäntehdas Oy. In their report, they deemed the school in Leipzig old fashioned, while they considered the Berliner Tischlerschule adequate and the Bauhaus Dessau most promising. In two separate articles, they praised the entire curriculum and teachers as being exemplary. ${ }^{64}$

Architect Salme Setälä (1894-1980) was among the early Finnish propagandists of the modern house, acknowledging the influences of Le Corbusier, Lily Reich, Mies van der Rohe, and Ludwig Hilberseimer in the new journal Tulenkantajat. ${ }^{65}$ The Finnish journal Domus (2/1932) presented a model flat for a self-supporting woman built inside the Stockmann department store in Helsinki. The model flat was designed by Werner West and included functionalist furniture, while the plan was a typical Existenzminimum plan with a foyer, toilet, kitchen cabinet, and one room. West's study trip to Dessau and the Bauhaus movement seemingly had an influence on this Existenzminimum ribbon-windowed design.

Haus am Horn for the Bauhaus Werkschau (Georg Muche, Weimar, 1923), the new concept of modest living spaces without the previous variety of utility rooms, was among the first of its kind, an architectural masterpiece designed by Bauhaus students. One of its most advanced features was the built-in kitchen by Benita Otte and Ernst Gebhard. The concept of a kitchen as a laboratory was something new, and this feature would be repeated all around the world during the next few decades. As Germany was already well ahead in this development, 


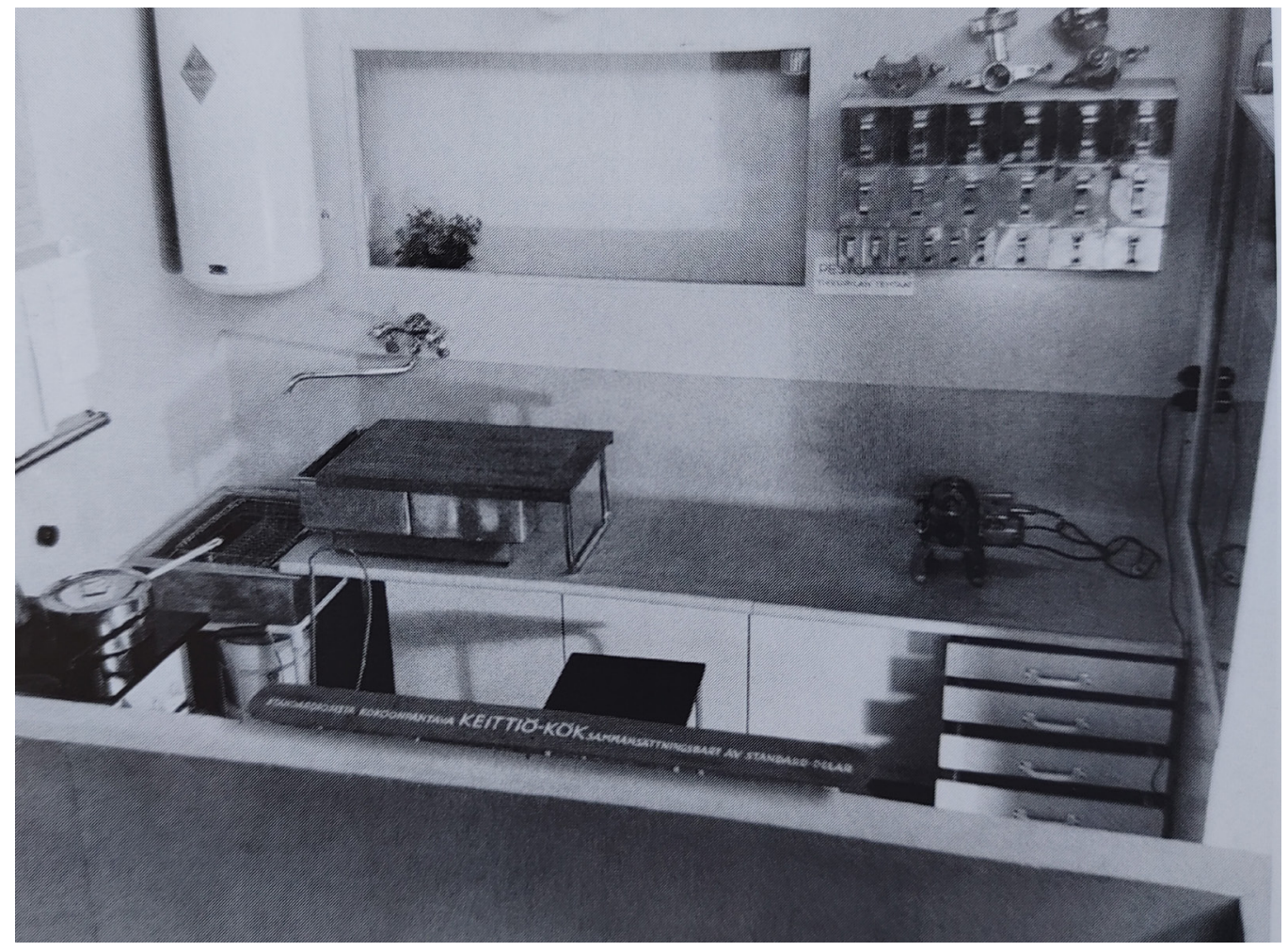

Figure 6. Kitchen from the Minimum Apartment Exhibition (Pienasuntonäyttely) in Helsinki, 1930. Aino Aalto's kitchen cabinet clearly shows Margarete Schütte-Lihotzky's influence. Photo: Aino Aalto, Museum of Finnish Architecture.

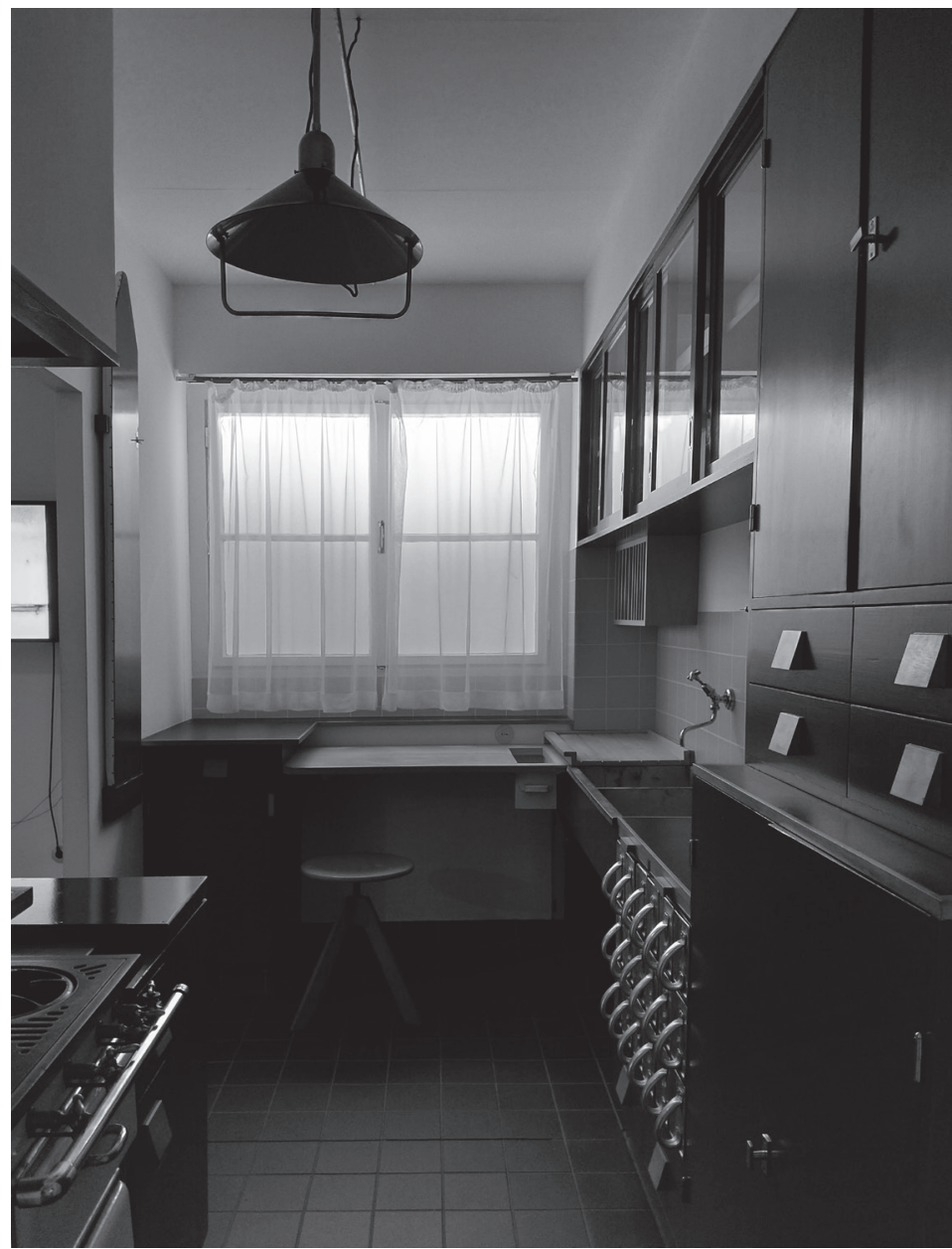

Figure 7. Frankfurt Kitchen, Margarete Schütte-Lihotzky, 1926, in MAK Vienna. Photo: Juhana Heikonen.

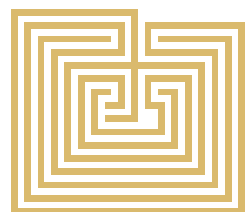




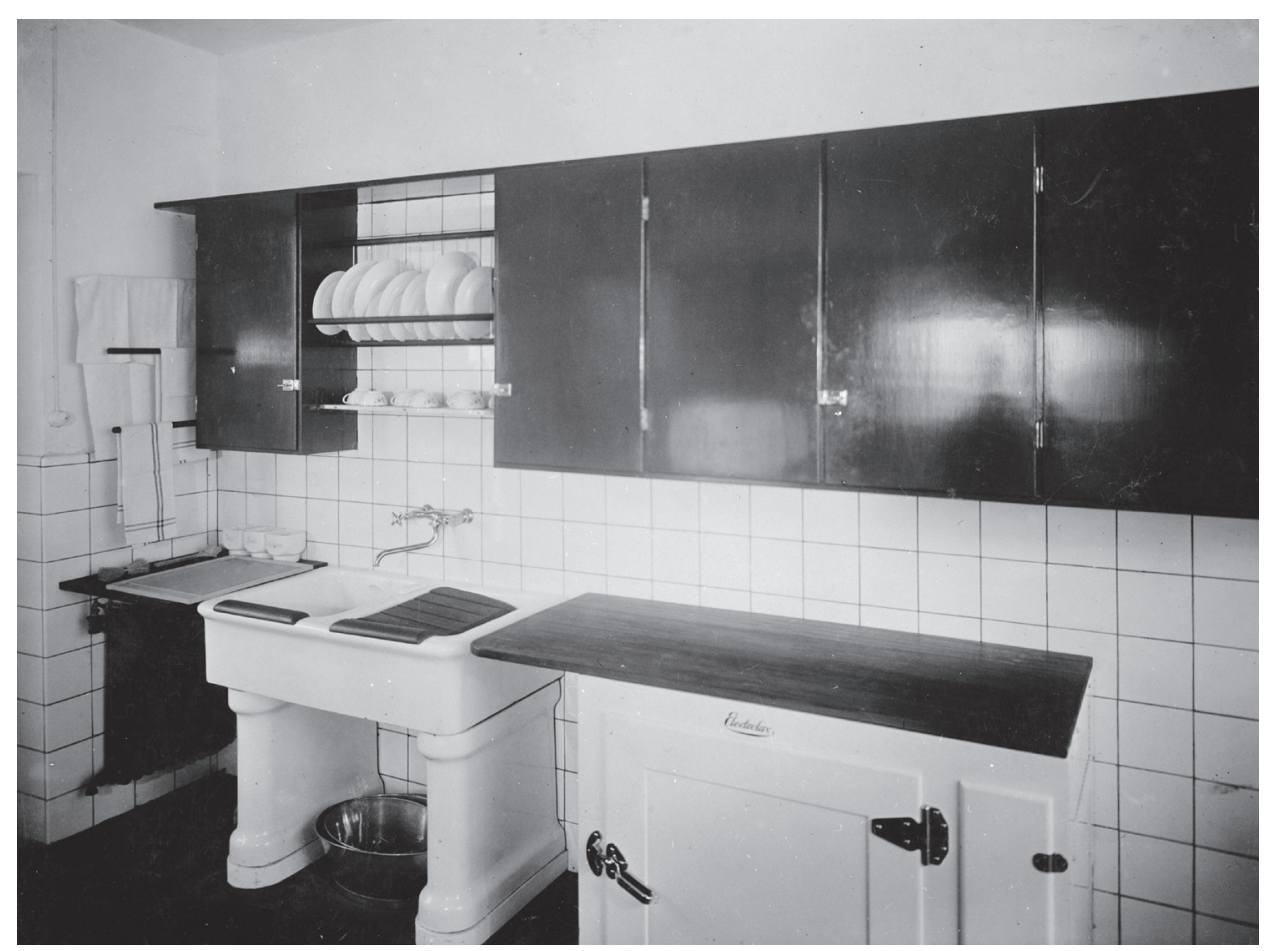

Figure 8^. "Bygge och Bo" exhibition at Liljevalchs Konsthall, 1928. A kitchen by Sven Markelius, which differs greatly from those of his German or Finnish contemporaries. Tekniska Museet, Stockholm.

Figure 9>.Apartment for an independent woman by Werner West and Keravan Puusepänteollisuus Oy, exhibition at the Stockmann's department store. The Existenzminimum and an inbuilt modern kitchen cabinet. Domus 2/1932.
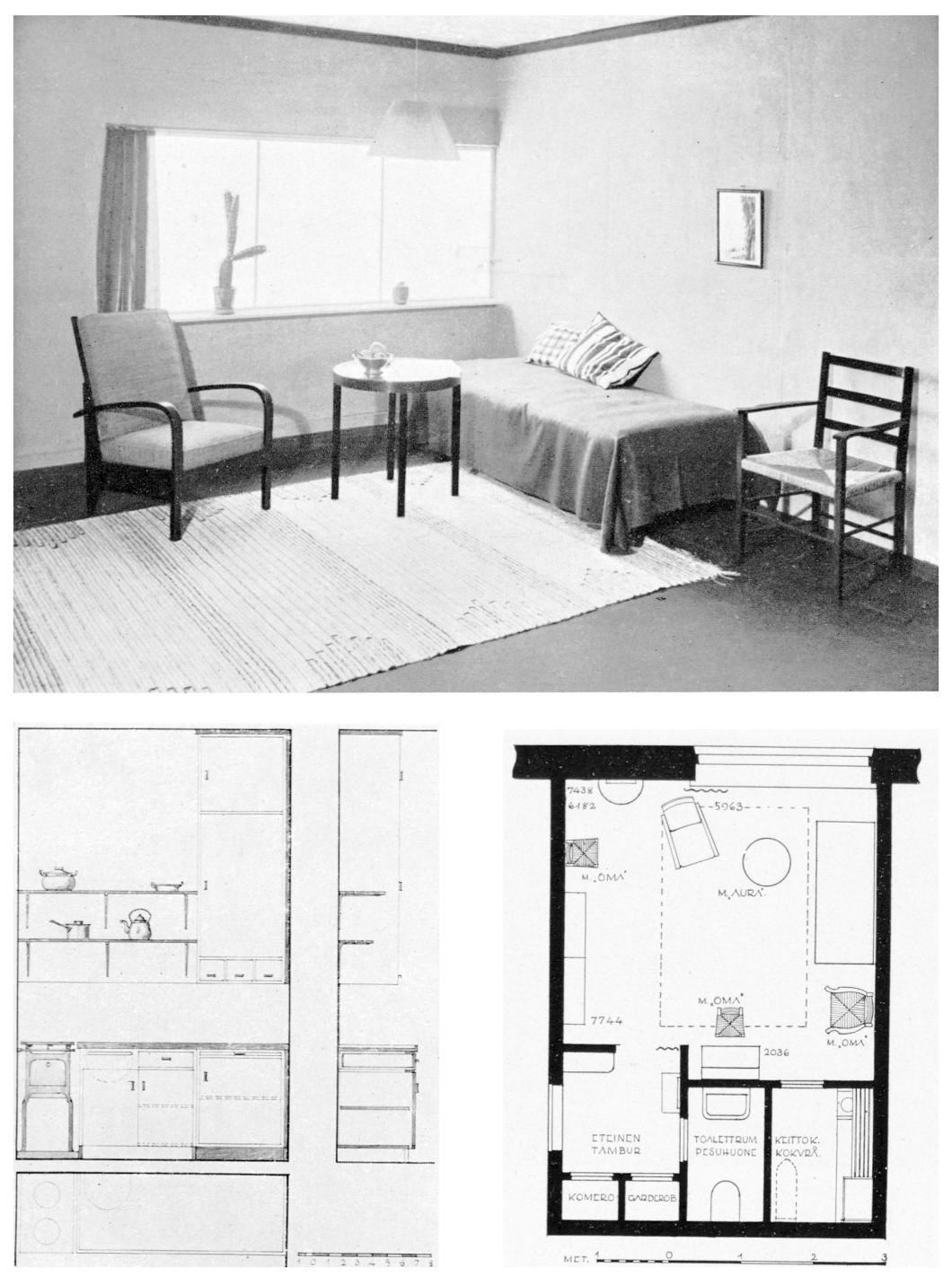

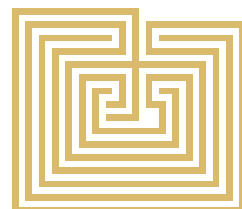


the concept was later perfected by architect Margarete Schütte-Lihotzky (1897-2000) with her Frankfurter Küche (1927), which was eventually installed in more than 10,000 of Ernst May's Neues Frankfurt apartments. According to Schütte-Lihotzky, the main concept came from train restaurant car kitchens, with their limited space. Cooking was separated as a space from eating. This space was usually in immediate proximity, though, just behind the next door. The discussion on whether the kitchen cabinets were too small continued in Finland throughout most of the 1930s, especially in the context of windowless kitchen cabinets with bad ventilation. While Erik Bryggman praised the new German Siedlungen housing estates, he also noted the problem with the kitchen cabinets using train restaurants as an influence. ${ }^{66}$ This notion proves that he was familiar with Schütte-Lihotzky's work, probably through Aino Aalto, who was among the first Finnish architects to analytically study the working economics and ergonomics of an apartment kitchen. ${ }^{67}$ According to Kirsi Saarikangas, the development of kitchens from isolated laboratories into an integrated living space in Olympiakylä was a crucial factor in Ekelund's creation of the modern family home. ${ }^{68}$

Swedish architects, working closely with the general public, also developed a new kitchen, called Standardköket, and these results were also published and displayed by the Helsinki Gas and Electric Works in a 1925 exhibition. ${ }^{69}$ The interest in a functional kitchen design was widespread at the time, ranging from private individuals to the national Martha Organization, ${ }^{70}$ and new solutions were actively published in journals like Kotiliesi and Rakennustaito. This new interest in in-built kitchens also gave rise to manufacturers like Keravan Puusepänteollisuus Oy, which was later owned by the department store Stockmann Oy.

As is typical in the Finnish case, the new wave of innovations first appeared in open design competitions. The insurance companies Elonvaara and Pohja organized a competition for a new, mixed-used office and apartment building in Helsinki (Kaisaniemenkatu). The winner was architect Oiva Kallio (1884-1964), while second prize was given to Hilding Ekelund. Both designs had ribbon windows, but eventually the apartments were rejected and the result became a full office building. Hilding Ekelund's proposal was an example of full functionalism, with efficient small apartments along with the required office spaces. ${ }^{71}$ The finished building was published in Arkkitehti. ${ }^{72}$ This brief prelude of functionalist housing architecture design was cut short by the 1929 financial crisis, only to be continued after 1933 .

\section{The End of Bauhaus and the Becoming of War}

The closure of Bauhaus Dessau was immediately reported in Arkkitehti. ${ }^{73}$ At the beginning of the 1930s, the mood had already turned against modern architecture. Germany's responsible administration was transformed to reflect the new regime and its tastes. This was already noted by Hilding Ekelund in his 1931 report on the Deutsche Bauausstellung. Ekelund later published an article by Professor Dr. Schmidt on the Deutsches Siedlungwerk, with Ekelund noting in his opening words that it did not represent the extreme views of the current regime. Schmidt wrote positively about the previous architectural style, even though he favored the new Heimatstil design with small houses, kitchen gardens, and sheds for animals and fodder. ${ }^{74}$ 

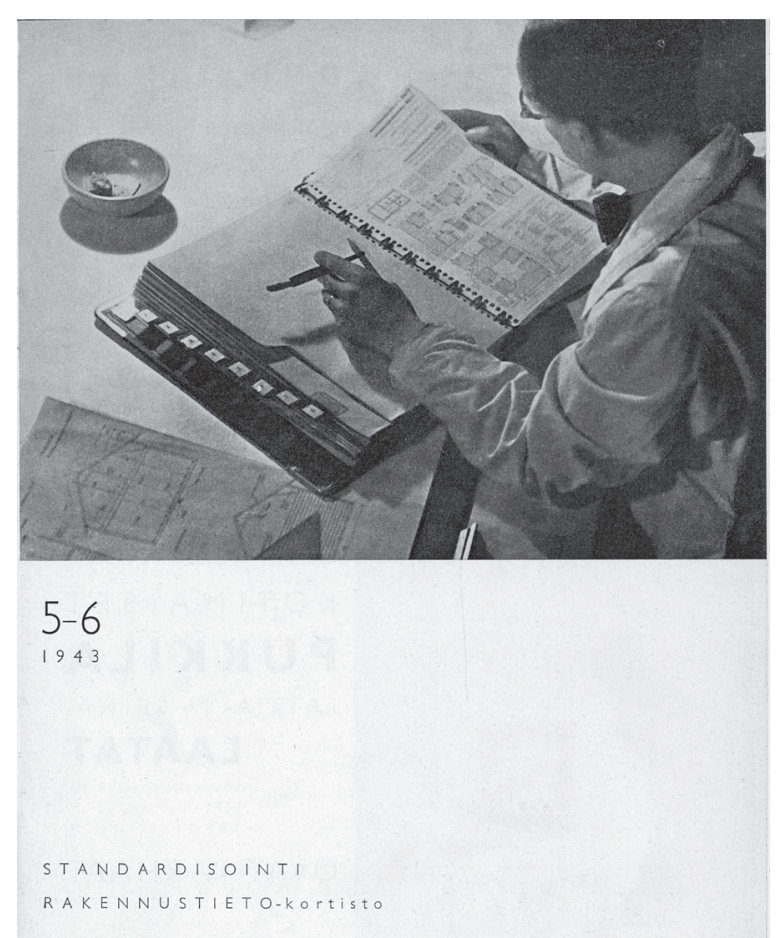

$\begin{array}{lllllllllll}\mathbf{A} & \mathbf{R} & \mathbf{K} & \mathbf{K} & \mathbf{I} & \mathbf{T} & \mathbf{E} & \mathbf{H} & \mathbf{T} & \mathbf{I}\end{array}$

JuLkaISIJA / SUOMEnarkkitehtilitto

Figure 10. The cover of Arkkitehti 5/6, 1943. This issue presented the new RT manual (on the cover) for rebuilding purposes, partially based on Ernst Neufert's Bauentwurfslehre.
Those affiliated with the Bauhaus movement fled Germany and became exiles throughout the world, but their influence on architecture continued, probably even more strongly in places like Tel Aviv and the U.S. But not all of them fled, like Neufert. He found new work in standardization and war mobilization under Albert Speer and the National Socialist regime. ${ }^{75} \mathrm{He}$ was also responsible for one of the most influential books on architecture ever: Bauentwurfslehre, first published in 1936 and selling out in weeks. The catalogue gave measures for everything from a toaster to an aircraft hangar, with thousands of illustrations, and it is still in print. This impact on design was, and is, beyond measure. Finnish standardization manuals are also based on Neufert's work, with Arkkitehti already reporting on the new manuals in issue no. 5/6, 1943 (the RT-kortisto)..$^{76}$ Much of Neuferts's influence cannot be detected in Finland before the war. However, Neufert's direct influence is evident in post-war rebuilding efforts all over the world. The journal Rakennustaito also analyzed the adoption of German modules and measurements $(125 \mathrm{~cm})$. Co-operation with Germany and the exporting of wooden-type housing to that country was relatively extensive at the time, namely by the company Finnish Puutalo Ltd. $^{77}$

Finland also cooperated in standardization practices with Sweden, but it was of less importance. The stark scale of progress between Germany and Sweden was best discussed in Arkkitehti $(5 / 6,1943)$, where Woldemar Baeckman wrote about the Swedish standardization project concerning standard doors. This was in stark contrast against Neufert's massive building manual.

The journal also reviewed one of the German wooden emergency lamellas designed to cover the housing shortage due to aerial bombings. It closely resembled some later postwar housing in Finland. The major national newspapers published discussions on standardization and post-war rebuilding efforts, including detailed discussions on the adoption of Neufert's modules and standard measurements. ${ }^{78}$

The manual's influence on housing companies in prewar Finland has not been well researched, but considering its immediate fame and usability, it must have strongly influenced the detailed design of apartment and floor plans since discussion on the German Existenzminimum style continued during 
the 1920s, throughout the war, and probably until the present day in certain medias. As an example, architect Ole Gripenberg (1892 1979) cited Neufert's manual already in 1938 in a disagreement concerning door widths. ${ }^{79}$

The 1939 house fair was held in the brand-new functionalist Helsinki Expo and Convention Centre, partially built to house the 1940 summer Olympics in Helsinki. The main curators were Hilding Ekelund and Kaj Englund. Aarne Ervi, one of the curators, wrote a short account of the fair and its features, including the new bomb shelters and the need to create architecture that conveyed softer lines and a sense of coziness and that was closer to nature, as in the new Olympiakylä, which was built to house future Olympic guests. This echoed Alvar Aalto's earlier stance in Arkkitehti. Aarne Ervi was overjoyed with the success of the opening on October 7, 1939, but regretted that the fair was shut down on the fourth day because the army confiscated the site for mobilization purposes. ${ }^{80}$ War broke out the next month.

Helsinki's Prewar Housing Companies and the German Influence

Over 20000 new modern apartments were built in Helsinki between 1930 and 1939. The developers and builders were very varied, but the majority were normal housing companies. The following examples are selected due to their varied developers and founders, and their architectural relevance to Bauhaus and German Siedlungen, such as the lamella, frame depth, façade detailing, or their architects known contacts to Bauhaus.

The housing company As. Oy Artturinlinna (Martti Välikangas, 1931-32) was originally founded by Arthur Nyman and later completed by several insurance companies. Välikangas celebrated the fact that the frame depth was between 7.5 and 11.5 meters, according to German principles. ${ }^{81}$ The first sketches resembled more a ribbon windowed streamlining, such as in Hans Scharoun's work. ${ }^{82}$ Välikangas designed several functionalist housing companies, such as As. Oy Eerikinkatu 33 (1933), also built as a tenement building.

The housing company As. Oy Lapinlahdenkatu 9 (Ole Gripenberg, 1933) was built by the Hartwall mineral water company for its employees. This very simple building consisted of medium-sized apartments (63-70 m2) and was fully furnished by Stockmann's Keravan Puusepänteollisuus Oy. ${ }^{83}$ At this point, Gripenberg belonged to the older generation of architects, but he still had an interest in updating his skills and ideas. One of the reasons could be that he was, like his many of colleagues throughout the first part of the century, also a developer. ${ }^{84}$

Harald Andersin also tried to re-open some previous urban structures in Sörnäinen. His designs for re-opening blocks 331 and 340 to Hämeentie partially succeeded, but only three lamellas were built before the war. He began his presentation in Arkkitehti by emphasizing the importance of large gardens and playgrounds. ${ }^{85}$ The only lamellas built before the war were designed by architects Väinö Vähäkallio, Georg Jägerroos, and Antero Pernaja. ${ }^{86}$ The more successful of these kinds of urban interventions was block 84 in Punavuori, facing Sinebrychoff Park. The traditional $19^{\text {th }}$-century closedblock plan was redesigned to include two block-length lamellas and, in between, two smaller buildings. Since the land was owned by the Sinebrychoff brewery, the plan was a relatively rare private development. The original plan by architect Karl Lindahl continued the surrounding closed-grid plan, despite the hilly terrain. Hilding Ekelund attacked this 


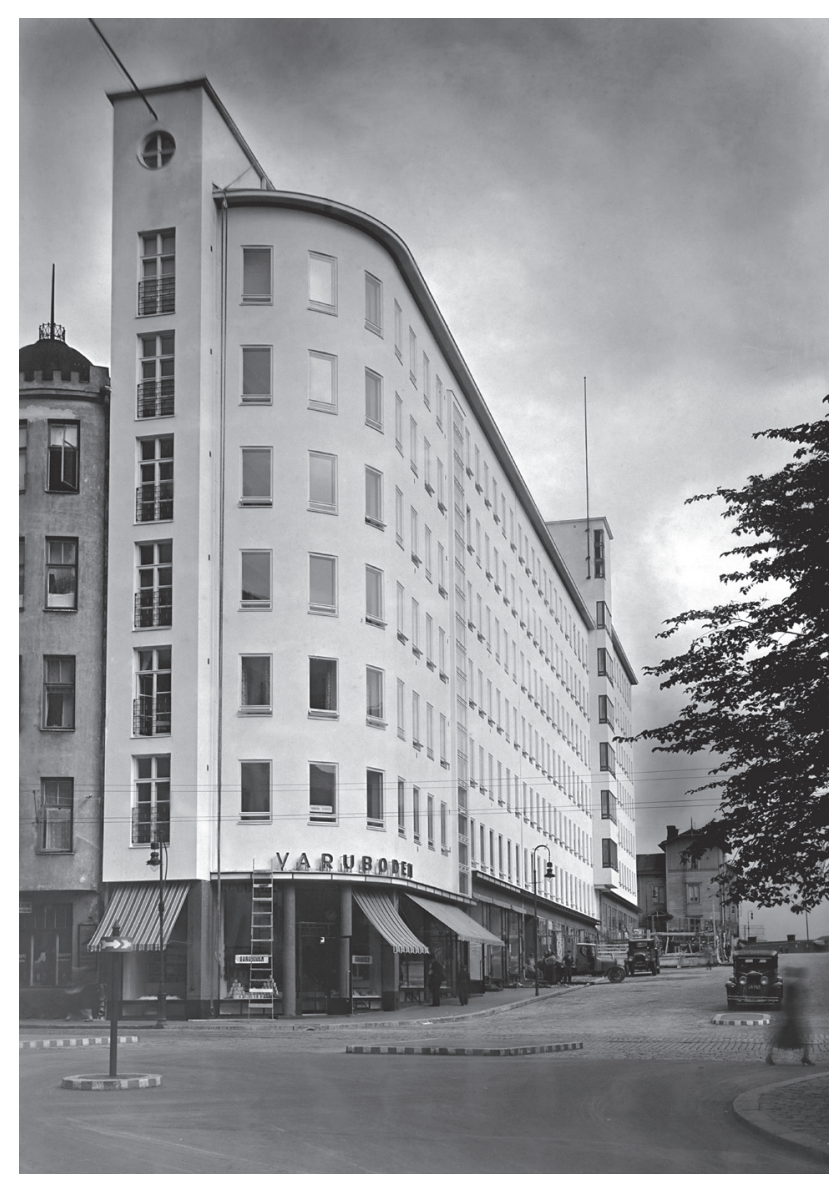

Figure 11. As. Oy Artturinlinna by Martti Välikangas, 1932. Photo: K. Havas, Helsinki City Museum.

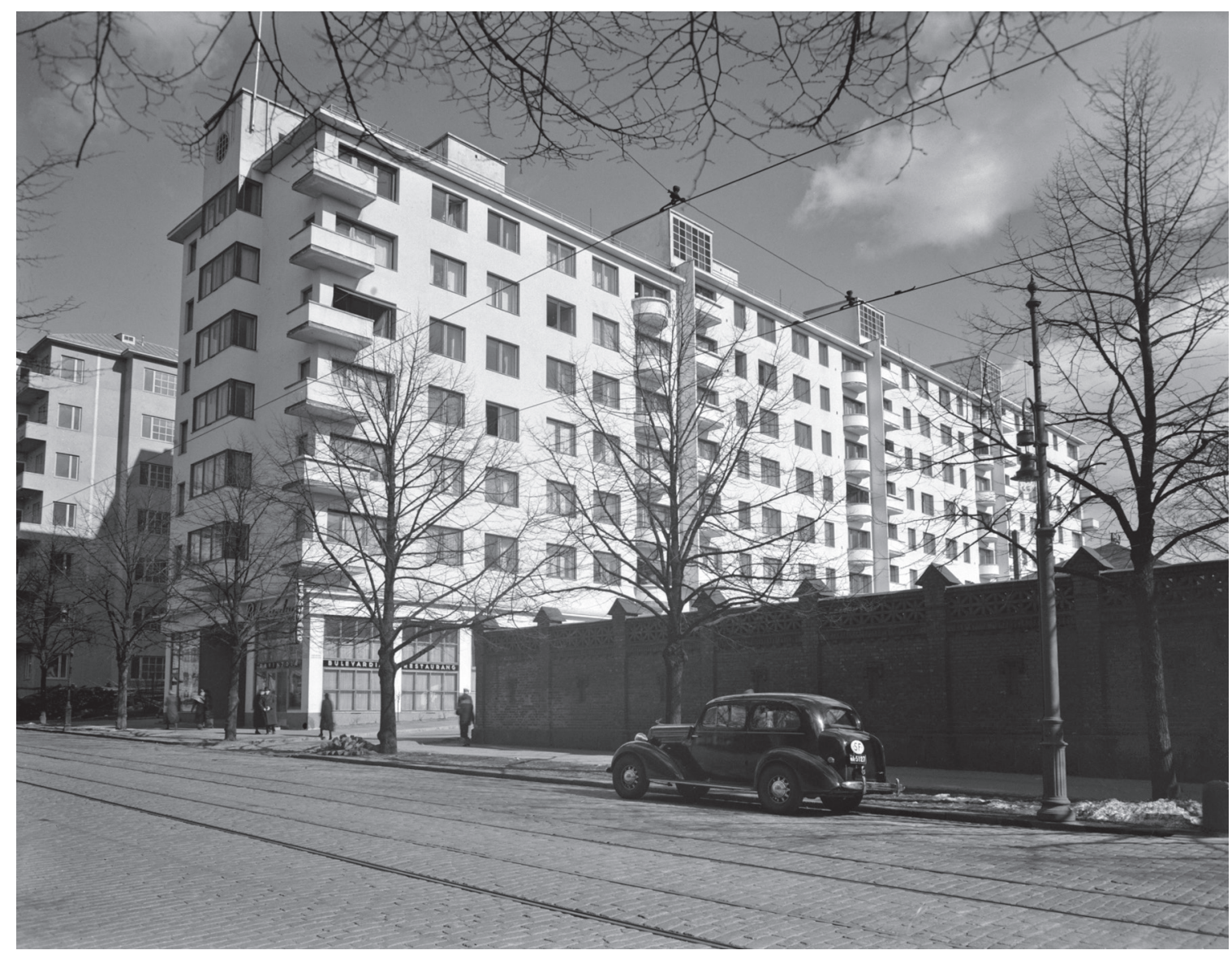

Figure 12. As. Oy Bulevardia, by Niilo Kokko, Arvo Aalto, and J. Saari, 1937. Photo: R. Roos, Helsinki City Museum. 


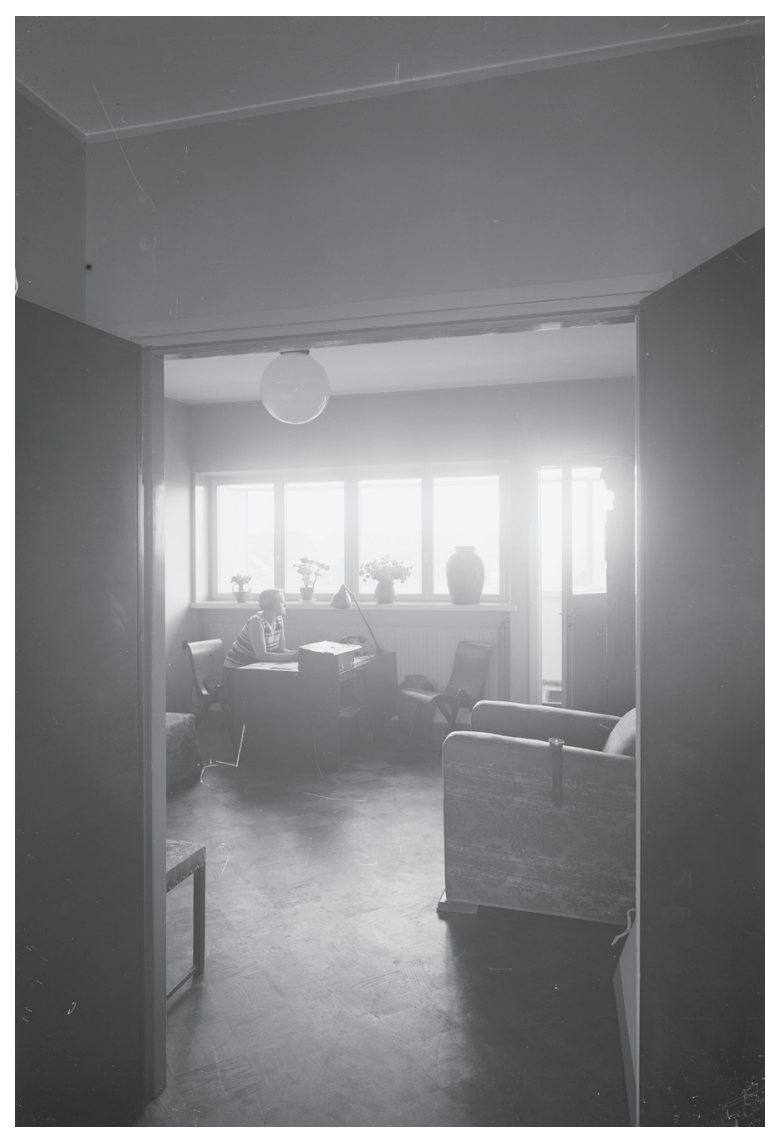

Figure 13. As. Oy Pohjois-Hesperiankatu 21, nicknamed "Töölön Helmi," Kaarlo Borg, 1932. A modern apartment room with strip windows. Photo: A. Pietinen, Finnish Heritage Agency.

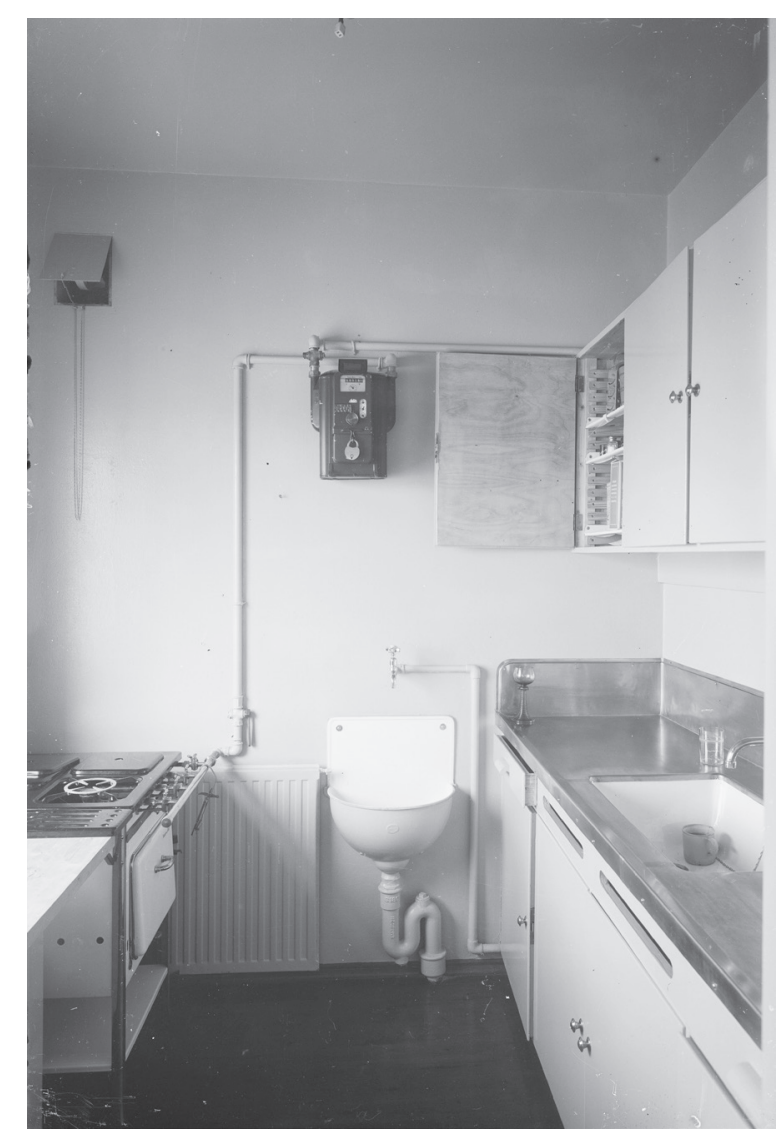

Figure 14. As. Oy Pohjois-Hesperiankatu 21, nicknamed "Töölön Helmi," Kaarlo Borg, 1932. The modern kitchen cabinet. Photo: A. Pietinen, Finnish Heritage Agency.

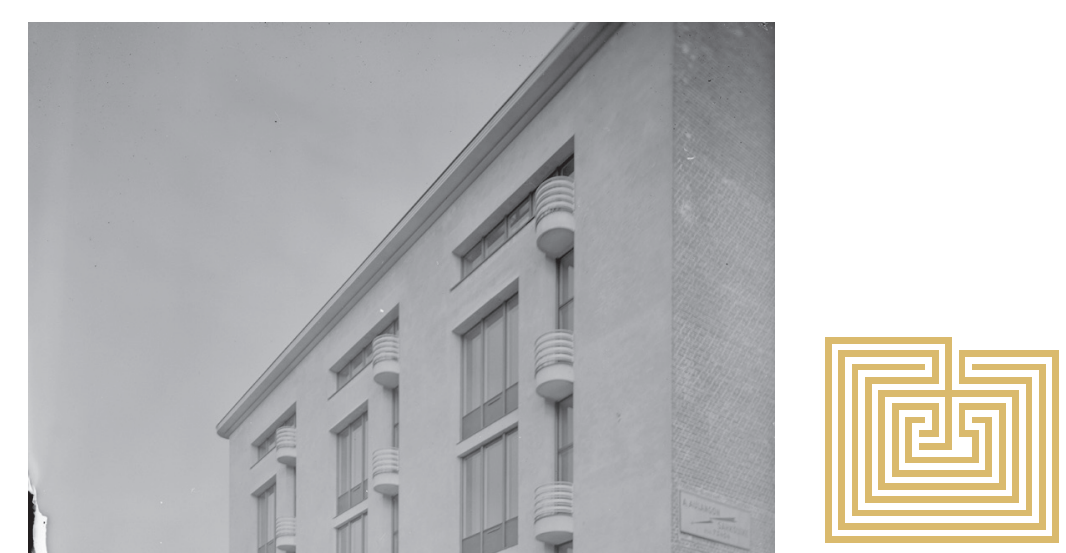

Figure 15. Lallukka, Gösta Juslén, 1933. Photo: A. Pietinen, Finnish Heritage Agency. 


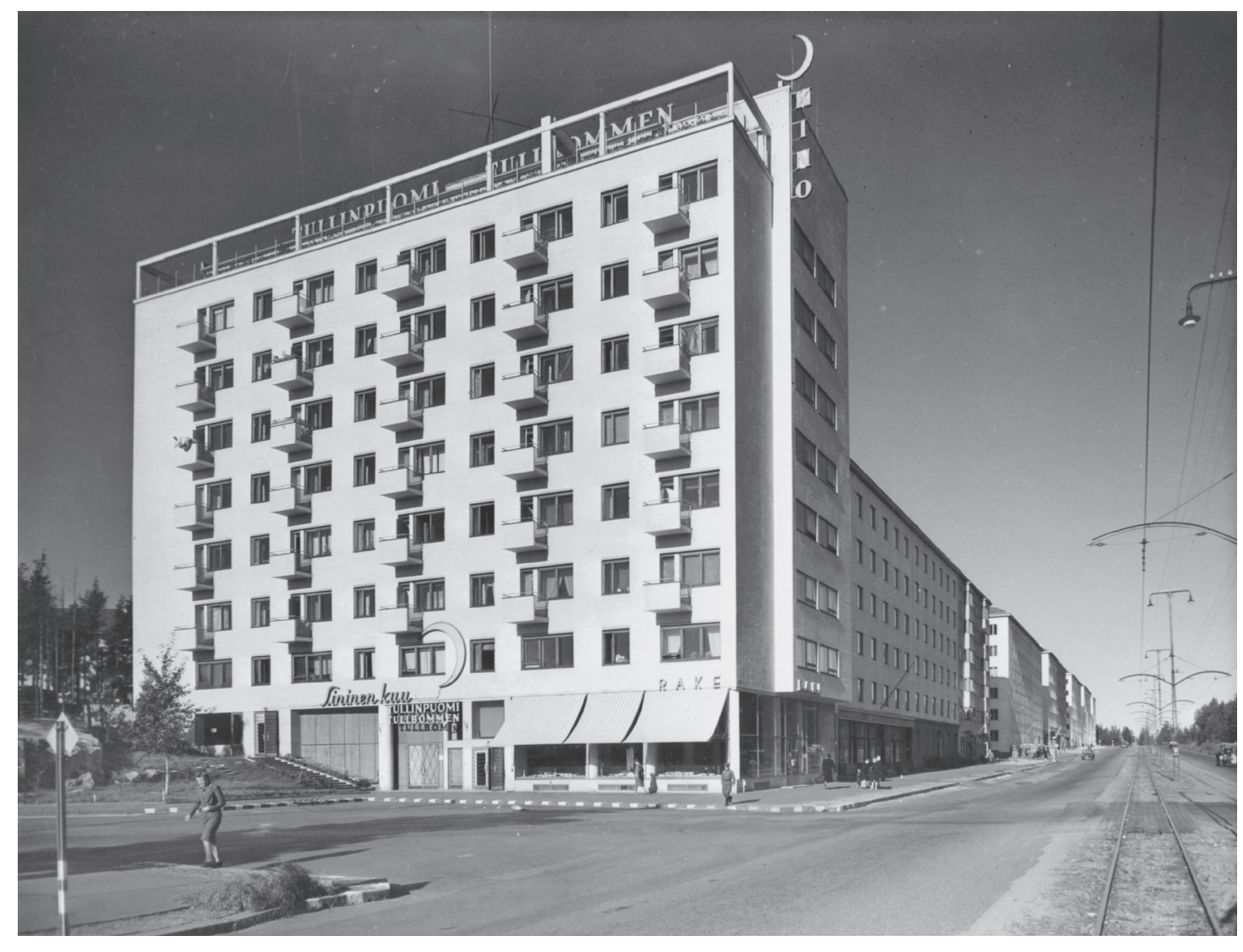

Figure 16. As. Oy Tullinpuomi, Olli Pöyry, 1940. Photo: A. Pietinen, Helsinki City Museum.

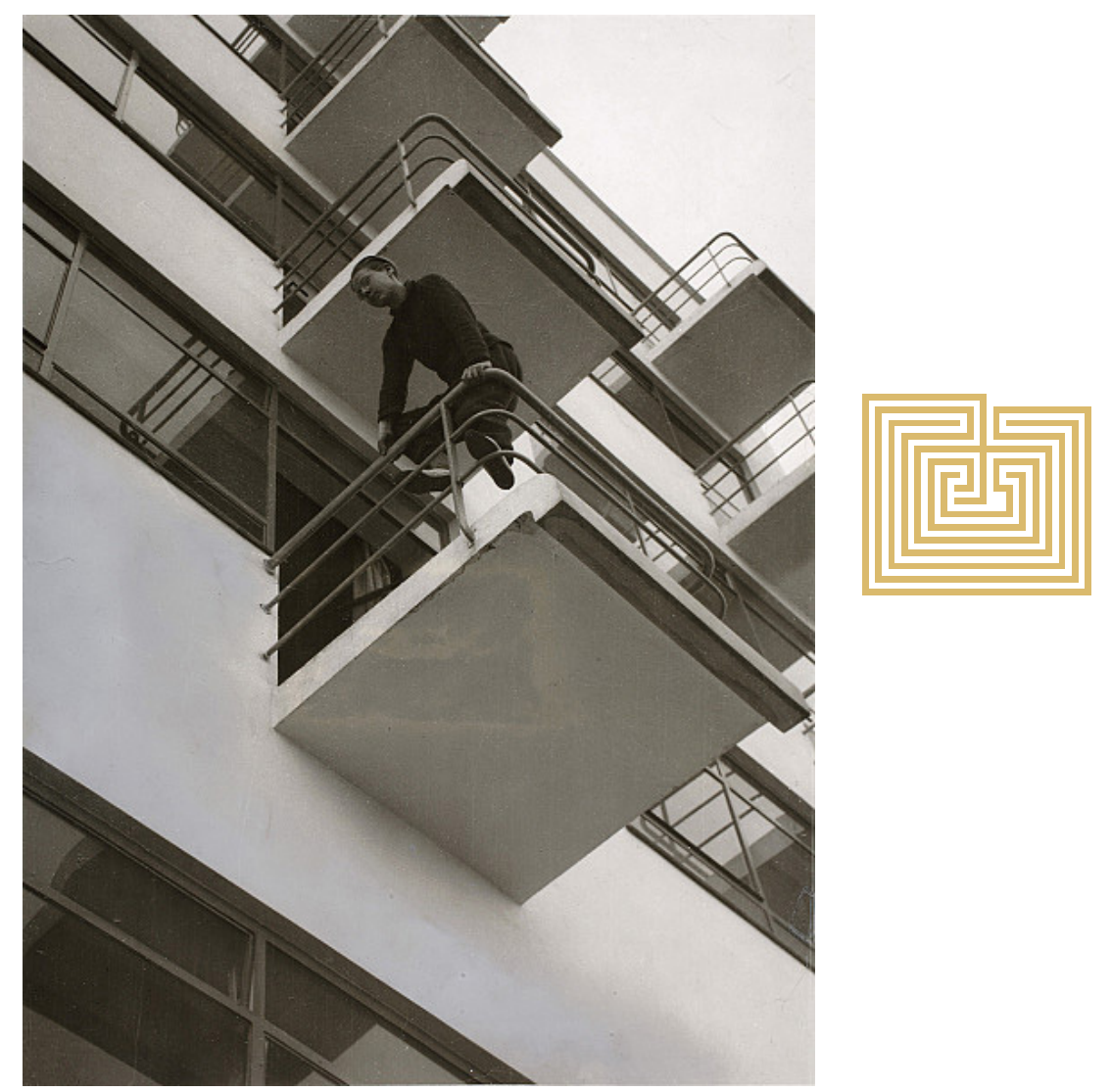

Figure 17. László Moholy-Nagy's photograph of Bauhaus balconies in Dessau, 1927. Photo: László Moholy-Nagy, Bauhaus-Archiv. 
old plan publicly in $1931,{ }^{87}$ prompting an irritated reply from the city in the next issue. ${ }^{88}$ Eventually, the brewery sold the land to investors and a new town plan was devised. The new founders of the As. Oy Bulevardia housing company included architects Niilo Kokko, Arvo Aalto, and J. Saari (for the lamella facing the park). ${ }^{89}$ The other founders in the neighboring housing companies included the developer-architect Ole Gripenberg, who also was part of this urban renewal scheme. ${ }^{90}$ One of the functionalist housing companies was designed by Kaarlo Borg, but with a humorous classical feature added to the bay windows: they were covered with diglyphs and metopes.

If Alvar Aalto had failed with his 14-story lamellas in Munkkiniemi, the new As. Oy Bulevardia housing company (1937) was the longest lamella in Finland at the time. The company also laid the foundation in an old-fashioned way: the building project was executed from start to finish by the shareholders. Forty-two of the housing company's flats were directly owned by the shareholders and another 54 by the company itself, thus by the shareholders as well. In addition to garages and a fine restaurant designed

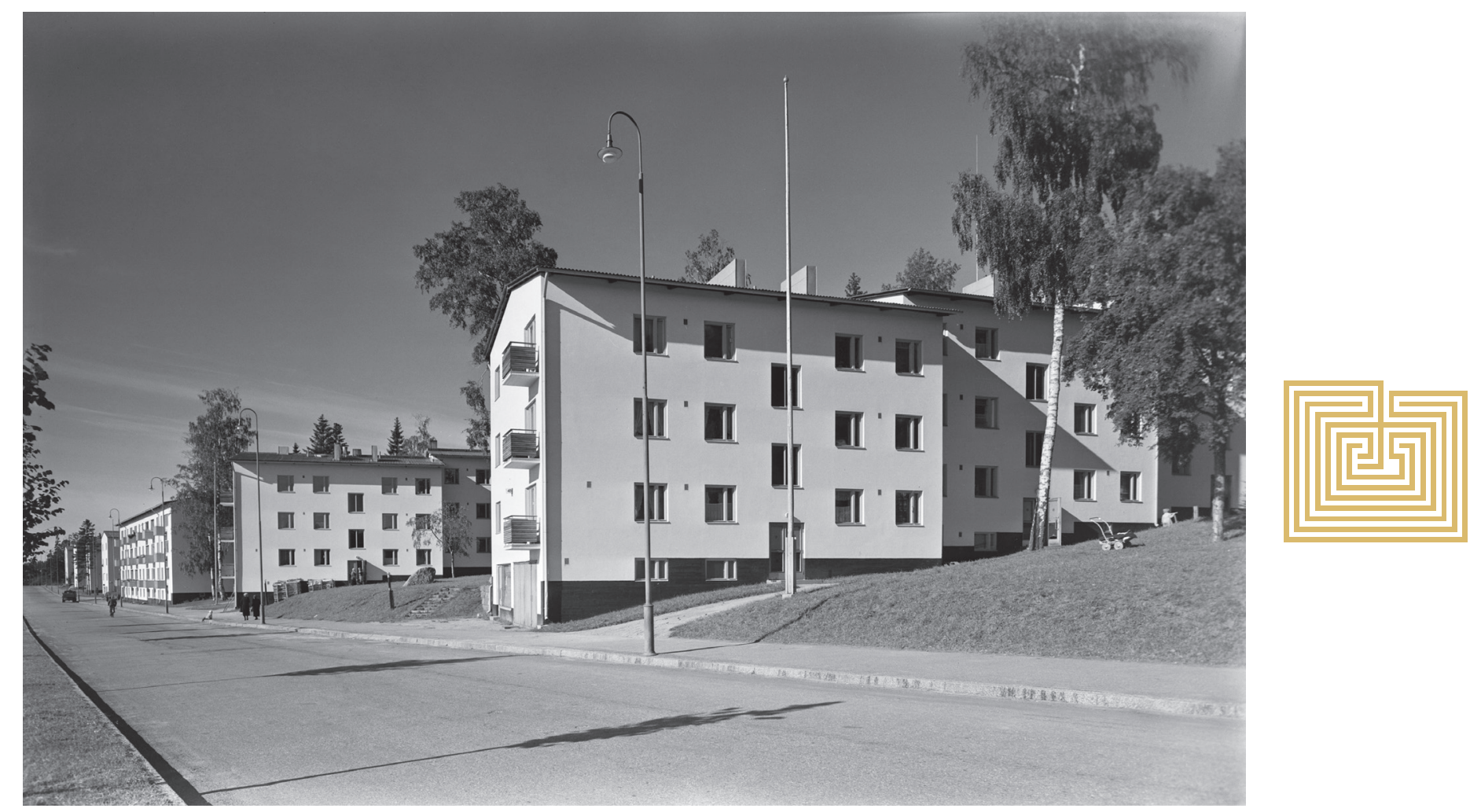

Figure 18. Olympiakylä, Hilding Ekelund, 1940. Image: A. Pietinen, Helsinki City Museum.

by the architects, the rents covered all the maintenance charges and later actually paid dividends to the shareholders. This kind of an arrangement was still quite typical in the 1920s, but it started to die out after the 1929 financial crash. Niilo Kokko together with Arvo O. Aalto developed a similar kind of project in Lauttasaari (As. Oy Klaarantie 9), but architecturally, with its diagonally stepped balconies, it belonged more to the post-war style compared to As. Oy Bulevardia's 1930s-style functionalism. ${ }^{91}$ Similar stylistic attempts at affecting town planning were made by Kaarlo Borg for a vacant plot on 
Tehtaankatu. His designs for six vast lamellas were never realized, though. ${ }^{92}$ However, he designed several other housing companies, such as As. Oy Pohjois-Hesperiankatu 21, nicknamed "Töölön Helmi" (1932), which was a tenement building with very expensive interior decorations, fridges and marble fireplaces..$^{93}$ The façade is dominated by bay windows and adjoining steel tube balcony fences in Bauhaus style. ${ }^{94}$ Töölön Helmi was built by the businessman Lauri Hallman as a personal investment. Borg's later work was assisted by students such as architect IImari Niemeläinen, who had visited Germany in 1936. ${ }^{95}$

One of the important groups of housing companies are the housing companies built by the co-operatives HOK and Elanto, which quite often adopted the Existenzminimum style. The smallest example was As. Oy Castréninkatu (Hilding Ekelund, 1934). ${ }^{96}$ Even though it was rebuilt on a closed city block, the 40 flats, ranging from $23.5 \mathrm{~m} 2$ to $32 \mathrm{~m} 2$, were well designed with a kitchen cabinet and toilet/shower. The builder was most probably Elanto (after it purchased part of the plot from the Finnish Lutheran Evangelical Society), and the building included a convenience store covering the whole ground floor. ${ }^{97}$ The building also had a rooftop terrace and a kindergarten. The façade is representative of typical functionalist style in Helsinki, except for the drawn-in balconied corner, which gives the false expression of two orthogonally colliding lamellas..$^{98}$

One of the most interesting functionalist projects in Etu-Töölö was the "Lallukka" housing company (Gösta Juslén, 1931-32). This was not a normal housing company of the time since it was executed after holding an open artistic design competition financed by Juho and Maria Lallukka. Above all, Lallukka was an artist residence. The competition caused a huge uproar, and no first prize was given. Eventually, Gösta Juslén's competition proposal, "Des Pudels Kern," was further developed. The published entries all represented the apex of the modernist movement, but they were mostly dismissed by the jury as unpractical. ${ }^{99}$ Juslén's proposition was further developed from ribbon windows to more traditional framing without losing its modern design. The finished house was published in Arkkitehti, demonstrating the building's exceptional façade, modern kitchens, and public areas with their tubular steel furniture. ${ }^{100}$ The highly modern interiors were already familiar because of Juslén's previous work with the Fazer confectionery and café (interior by architect Jarl Ekelund, 1930), which were partially furnished (again) by Stockmann and Werner West, with whom he had already visited Bauhaus Dessau.

Since Juslén had worked and studied in Germany, a certain resemblance can be detected with the small balconied façade and Bauhaus dormitory in Dessau. This Bauhaus feature was also noticed by Nils Gustav Hahl, one of the founders of Artek, who wrote an article on the finished house and its brightly colored detailing, reminiscent of Bauhaus. ${ }^{101}$ In Lallukka's case, the client was the design competition jury, consisting of two artists, two lawyers, and as chairman the architect Onni Tarjanne. Juslén designed several housing companies in Helsinki for a variety of clients, from banks and foundations to private investors. One of the more unusual ones was the housing company As. Oy Merimiehenkatu 39 (1938), which was the only completed example of a double frame lamella house, already proposed by Hilding Ekelund at the 1932 Nordic Building Forum based on an even earlier design by Ole Gripenberg (1930). ${ }^{102}$ 
The housing company As. Oy Tullinpuomi (Olli Pöyry, 1939) was built by the nonprofit building company HAKA after a design competition, where Pöyry came in second. ${ }^{103}$ In the new town plan, the newly proposed Tullinpuomi building represented well the new functionalist style, and it was rather special for being eight stories high and including a rooftop restaurant and cinema as well as ground-level shops. Moreover, this was still meant to be low-income housing. The white façade was dotted with evenly placed small boxy balconies, already a familiar design feature from Juslén's Lallukka and Bauhaus Dessau. ${ }^{104}$ Since the floorplans did not correlate with the façade, and since one apartment may include two or three balconies, Pöyry's balcony arrangement can be seen as an intentional stylistic choice pointing to Dessau.

This article has provided a brief overview of some prewar examples of housing companies in Helsinki, where the influence of the German Siedlungen or Bauhaus movement can be detected. The principles of German Siedlungen were not executed in buildings in Helsinki before Olympiakylä, but instead in more distant locations like the industri- al town Sunila (Alvar Aalto, 1936-39). This complex of mass housing estates required centralized funding and planning, and thus, does not concern private housing companies constructed individually based on a ready town plan. However, the finer details were adopted: lamella, frame depth, sun angles, new functional living arrangements, such as inbuilt kitchens.

\section{Conclusions}

Since most of the exchange of architectural ideology and practice is circumstantial, when not a direct copy, we must study personal networks, movements, and literary influences. When the Bauhaus movement became well known among Finnish architects and the wider public it was most probably the result of indirect influence, and the results can be detected in the original designs of Helsinki's housing companies and their reception in the press. Especially Gropius' writings and public speeches influenced Helsinki's architects, engineers, contractors, and developers. I argue that Neufert's influence on the design of housing in general was greater, particularly during the postwar decades, but his role and meaning has not been researched before.
The mixed views on Swedish influence were perhaps best described by Nils Erik Wickberg in Byggnadskonst i Finland (1959). The 1929 Turku Fair, which preceded the 1930 Stockholm Fair, represented the breakout moment for functionalism in Finland, and its architects were inspired by their close friend Gunnar Asplund's turn from classicism to functionalism as much as by Le Corbusier and Bauhaus. ${ }^{105}$ Architect professor Nils Erik Wickberg's view was identical with Ekelund's opinion about the overestimation of Swedish influence. Wickberg and Ekelund were colleagues and contemporaries in promoting functionalism, unlike later researchers on the subject. It is possible that the personal and amicable contacts among Nordic architects has been overemphasized in prior studies at the expense of other direct and literary contacts to Germany. On the other hand, prior research has not distinguished between the various building types characteristic of Finnish modernism, such as public and private buildings. The architects of Helsinki's housing companies were a different group from the more famous architects of public buildings. Alvar Aalto's Standard Tenement Building in Turku (1929) had its forerunners 
in Germany, not in Sweden. On a more practical level, with respect to housing companies the Germans had by 1930 built modern hygienic and compact mass housing units in the tens of thousands and the Dutch in the thousands, whereas the French had built close to zero and the Swedes none at all. This would also mean that Finnish architects had mostly been exposed to German examples both through their travels to Germany and in printed publications.

The postwar rebuilding of Finland and Helsinki to house the demobilized army and the 430,000 (1/8 of the whole population) refugees from Soviet-annexed Karelia witnessed new town planning based on Siedlungen. Such planning was executed by several contractors and individual housing companies and backed by state loans. The production of housing in Helsinki during the 1950s and 1960s was in relative and absolute numbers a third higher than at any time since. This was due to a shifting ideology regarding the involvement of the state and the city in housing production and town planning. The reliance on markets solely had proven unable to resolve the dire need for housing. Architects based their plans on the German model of
Siedlungen and standardization. Standardization was based largely on Neufert's work. He had close connections with Finland, he was part of the Bauhaus movement, and before his later career in the National Socialist regime Neufert had worked directly under Gropius.

The German Siedlungen received the greatest share of publicity in the Finnish professional press, and the Bauhaus movement was well known from the start. Finnish architects and engineers were well read on the subject, many of them had visited Weimar and Dessau and some of them personally knew the people involved with the Bauhaus movement. Even though direct prewar influences are harder to pinpoint, they can be found in discussions concerning Gropius, building frame designs, and even in some detailing borrowed for Helsinki's housing companies.

\section{Endnotes}

1 This research has been conducted as part of the University of Helsinki's "Law, Governance and Space: Questioning the Foundations of the Republican Tradition" project (director Prof. Kaius Tuori) and has received funding from the European Research Council (ERC), under the European Union's Horizon 2020 research and innovation programme (grant agreement No 771874). I would also like to thank Prof. Kirsi Saarikangas, Ad. Prof. Renja Suominen-Kokkonen, Dr. Erik Hieta, the editors of this publication, and the two anonymous reviewers for their help.

$2 \quad$ See endnote 4 and below in Foreign influences.

3 Baugennossenschaft closely resembles a housing cooperative or a housing association and should not be mistaken for a building cooperative. $4 \quad$ Osakeyhtiölaki, Limited Liability Companies Act, previously used to form jointly owned real estate ventures before the 1926 Limited Liability Housing Companies Act.

$5 \quad$ Wohnungseigentürmergemeinschaft is a private association-like entity often formed either ipso jure in a building with multiple owner-occupancies, or by a real estate developer for the purpose of marketing, managing, and selling homes and lots in a residential subdivision. In Germany, the members are also registered individually as owners of the allotted plot of land, where, in contrast with a housing company, the owner owns only stock.

$6 \quad$ Further on, housing company even though there is no exact translation to this specifically Finnish model of building, owning, financing, and trading of real estate, etc.

$7 \quad$ Hilding Ekelund, "Rakennustaide ja Rakennustoiminta 1918-1947," in Ragnar Rosén, Erik Hornborg, Eino Jutikkala and Heikki Waris (eds.), Helsingin kaupungin historia, Vol. 1 (Helsinki, 1962), 101-136. Hilding Ekelund (1893-1984) was 
an architect and later also worked as a teacher at the Department of Architecture and as a town planner in Helsinki.

.

9 Riitta Nikula, "Funktionalismi," in Ars -

Suomen taide, Vol. 5 (Helsinki: Kustannusosakeyhtiö

Otava, 1990), 96; Pekka Helin, "Asumisen

arkkitehti," in Timo Tuomi (ed.), Hilding Ekelund

(1893-1984) - Arkkitehti, arkitekt, architect (Suomen

rakennustaiteenmuseon monografiasarja, 1997),

178; Petri Neuvonen (ed.), Kerrostalot 1880 - 2000

- Arkkitehtuuri, rakennustekniikka, korjaaminen

(Rakennustieto Oy, 2006), 54.

10 Raija-Liisa Heinonen, Funktionalismin läpimurto Suomessa (Helsinki: Rakennustaiteen museo, 1986). The focus throughout the book is on Swedish influence, but the book also includes examples of German influence. On Birger Brunila, see 202; on Alvar Aalto, see 203, 219, 239; on P. E.

Blomstedt, see 266; on the foreign architectural press reviewed in Finland, see 282

$11 \quad$ Kirmo Mikkola, "The transition from

classicism to functionalism in Scandinavia," in Asko

Salokorpi (ed.), Classical Tradition and the Modern

Movement (Finnish Association of Architects, Museum of Finnish Architecture, Alvar Aalto Museum, 1985) 42-74.

12 Tobias Hoffman (ed.), Nordic Design. Die Antwort aufs Bauhaus (Stuttgart: Bröhan Museum und arnoldsche Art Publishers, 2019).

$13 \quad$ Atli Magnus Seelow, "From the Continent to the North - German Influence on Modern Architecture in Sweden," Konsthistorisk tidskrift, 85, no. 1 (2016): 49.

14 Petri Neuvonen, Erkki Mäkiö, and Maarit Malinen, Kerrostalot 1880-1940 (Rakennustietosäätiö Oy, 2002); Esko Nurmi, Laura Puro, and Martti Lujanen, Kansanosake - Suomalaisen asuntoosakeyhtiön vaiheet (Suomen Kiinteistöliitto Ry, 2017); Elina Standerskjöld, Arkkitehtuurimme vuosikymmenet 1930-1950 (Suomen rakennustaiteen museo, Rakennustietosäätiö RTS and Rakennustieto Oy, 2008).

15 Tommi Lindh, Töölöläisfunktionalismin 4 vaihetta (Teknillinen korkeakoulu, 2002), 119. 16 Rakennustaito, no. 14 (6.7.1935): 14-15 17 Uusi Suomi, "Sunnuntailiite," no. 179 8.7.1934, 2; Suomen Sosialidemokraatti, no. 222, 16.8.1936, 8 .

18 Rakennustaito, no. 19 (15.9.1934):

19-20. Elna Kiljander made her career in designing functionalist housing and especially kitchens.

19 Nurmi, Kansanosake - Suomalaisen asuntoosakeyhtiön vaiheet, 85-91.

20 Tommi Lindh, Töölöläisfunktionalismin 4 vaihetta (Teknillinen korkeakoulu, 2002), 58-61. 21 As. Oy is an abbreviation for Asuntoosakeyhtiö, or as translated word for word, Limited Liability Housing Company.

22 Rakennustaito, no. 19 (24.9.1937): 340.

23 Rakennustaito, no. 8 (21.04.1939): 124-

125.

$24 \quad$ Lamella house is probably a less wellknown term in the anglophone world. A lamella would be a unit of housing consisting of a main staircase usually two or three apartments per landing. By connecting such lamellas, one gets the typical, sometimes even hundreds of meters long, lamella houses.

25 See endnote 4 and Foreign influences 26 Turun Sanomat, no. 301, 03.11.1929: 1. $27 \quad$ Arkkitehti, no. 7 (1.7.1929): 114-116. For a closer look at the Turku fair, see Elina Standertsskjöld, "The Turku fair of 1929, a manifesto of functionalism," in Riitta Nikula (ed.), Erik Bryggman 1891-1955, arkkitehti, arkitekt, architect (Suomen rakennustaiteenmuseon monografiasarja, 1991). 28 Riitta Nikula, "Funktionalismi", 95. 29 Arkkitehti, no. 6 (1.6.1932); Raija-Liisa Heinonen, "Funktionalismin läpimurto Suomessa," 214-216.
$30 \quad$ Arkkitehti, no. 7 (1.7.1934): 108 $31 \quad$ Arkkitehti, no. 9 (1.9.1937): 33-35. A short report by Hilding Ekelund on the third general housing congress.

32 Rakennustaito, no. 17 (22.8.1931): 257266.

33 Uusi Suomi, "Sunnuntailiite", no. 310, 15.11.1931, 1: 4. Gustaf Strengell (1878-1937) was an architect and among the crucial architectural theorists and polemists until the 1930s.

$34 \quad K o t i l i e s i$, no. 16 (15.8.1932): 614-616

35 Eva Kuhlefeldt-Ekelund, "Matkakertomus," Arkkitehti, no 2 (1.2.1932): 26-28. Eva KuhlefeldtEkelund (1892-1984) was married to Hilding Ekelund, with whom she travelled widely in Europe. 36 Rakennustaito, no. 1 (1.1.1928): 6-8. Vietti Nykänen (1884-1951) was probably more active in far-right wing politics than architecture. He was also an active member of several far-right political organizations, including the Finnish National Socialist Party. His more direct activities included a planned military coup to overthrow the left-center government in 1938. This could also explain his highly critical view of Dessau's left-wing housing projects.

$37 \quad$ Atli Magnus Seelow, "The Stockholm

Exhibition 1930 - The Swedish Reception of German Functionalism," in Nordic Design. Die Antwort aufs Bauhaus, 101.

38 Timo Tuomi, Elina Standerskjöld, Kristiina

Paatero, Eija Rauske, and Esa Laaksonen (eds.),

Matkalla! En Route! (Museum of Finnish Architecture,

1999). The excellent book gives a closer look at

Finnish architects' excursions in Europe.

39 Petri Neuvonen, Erkki Mäkiö, and Maarit

Malinen, Kerrostalot 1880-1940 (Rakennustietosäätiö Oy, 2002), 17

$40 \quad$ Uusi Aura, no. 157, 10.06.1928: 1; Turun Sanomat, no. 157, 10.06.1928: 1; Åbo Underrättelser, no. 158, 10.06.1928: 1; Turun Sanomat, no. 301, 03.11.1929: 1 .

41 Rakennustaito, no. 4 (23.2.1935): 49-52. 
(1.12.1931): 616-618

$45 \quad$ Arkkitehti 1.8.1935, no 8: 30

46 Turun Sanomat, no. 180, 10.7.1931: 1, 4

The focus of the article was Siegfried Giedion's article on Finnish architecture (Bauwelt, 18.6.1931). Finland also affected Moholy-Nagy's family: his daughter was named Hattula to honor the medieval church of Hattula and its frescos. Professor Hattula MoholyNagy is currently responsible for cataloguing her father's estate.

47 Mia Hipeli, "Aino Aalto as a Photographer," in Ulla Kinnunen (ed.), Aino Aalto, (Alvar Aalto Museum, 2004)

48 Göran Schildt, "Aalto, Bauhaus and the Creative Experiment," in Kirmo Mikkola (ed.), Alvar Aalto vs. the Modern Movement (Rakennuskirja Oy, 1981). Göran Schildt (1917-2009) was, among other pursuits, an art historian, but he became famous as Alvar Aalto's first biographer. As in the context of Bauhaus, he was very often highly critical of his friend.

$49 \quad$ Peter Blundell Jones, From Essence to Appearance: Parallels Between the Working Methods of Alvar Aalto and Hugo Häring in Arq (London, 2015), 334-348.

$50 \quad$ Arkitehti, no. 3 (1.3.1926): 40

$51 \quad$ Arkkitehti, no. 6 (1.6.1929).

$52 \quad$ Turun Sanomat, no. 265, 1.10.1933: 1

53 Arkkitehti, no. 9 (1.9.1936): 35-36.

The model illustrations show a woman ironing a shirt and the required space for it, as well as the measurements of a boxing ring, where the knockedout opponent is lying on the floor.

$54 \quad$ Aamulehti, no. 334, 10.12.1942: 5. In Aamulehti's report, Aalto spoke again about the need to base standardization on nature and the human factor, and to avoid aiming for monotonous types of houses. Neufert gave a speech on the German standardization process as well. Arkkitehti, no. 5-6 (1.5.1943). The whole issue was about the new RT manual.

$55 \quad$ Arkkitehti, no. 9 (1.9.1938): 129-131.

$56 \quad$ On Reijola, see Arkkitehti, no. 4 (1.4.1931):

50-51; on Kulosaari, see Arkkitehti, no. 6 (1.6.1931):

50; on Meilahti, see Arkkitehti, no. 9 (1.9.1932): 34

57 Timo Tuomi, "Hilding Ekelund

kaavoittajana," in Tuomi, Hilding Ekelund (1893-

1984), 166; Arkkitehti, no. 3 (1.3.1941): 48-48.

$58 \quad$ Arkkitehti, no. 3 (1.3.1938): 34-35.

$59 \quad$ Arkkitehti, no. 6 (1.6.1932): 84-86

60 Riitta Nikula, "Rakennustaiteen 1920- ja

1930-luku," in Ars - Suomen taide, Vol. 5. 106

Arkkitehti, no. 3 (1.3.1934): 35.

$61 \quad$ Riitta Nikula, "Funktionalismi," 95; Pekka

Helin, "Asumisen arkkitehti," 181.

62 On Siltasaari, see Arkkitehti, no. 4

(1.4.1935): 49-50; on Töölönlahti, see Arkkitehti, no 3 (1.3.1937): 39; on Norrmalm, see Arkkitehti, no. 6 (1.6.1934): 87.

$63 \quad$ Birger Brunila, "Asemakaavoitus 1918 -

1945," in Helsingin kaupungin historia, Vol. 1, 63-64.

64 Lauri Kuoppamäki, "Puuseppäteollisuuden ammattiopisto," Lahti, no. 49, 30.04.1929: 5;

"Dessaun puuseppäkoulu," Lahden Sanomat, no. 53, 16.05.1929, 4. Gustav "Gösta" Juslén studied in Helsinki but completed his studies in Munich

before WWI, where he also worked for a brief period. Werner West was head of design in the furnishing design department at Stockmann department store and among the first designers of tubular steel furniture in Finland. Director Peltonen, of Keravan Puusepäntehdas Oy, later owned by Stockmann department store, was responsible for furnishing hundreds of kitchens in Helsinki. Both newspapers spell Juslén incorrectly as Juslin. This mistake is easily made when transcripting from cursive. Also, there was no architect named Juslin, while on the other hand Juslén's older brother, Karl Eskil Juslén (1881-1958), was the procurator of both Keravan
Puusepäntehdas Oy and its owner, Stockmann. Juslén would cooperate with the latter companies (and his brother) throughout his career.

65 Tulenkantaja, no. 1-2 (3.1.1929): 15-17. The article "Huomispäivän koti" was widely cited in other journals, such as Puuteos, no. 1 (1.2.1929). 66 Granskaren, no. 7-8 (1932): 91-93. This special issue was published for the Nordic Building Forum in Helsinki and its subject was functionalism in general. The issue also included critical comments on apartment standardization by Gunnar Granqvist, Anna-Lisa Stigell, Sigurd Frosterus, J. S. Sirén, Walter Qvist, and Bertel Jung in the main articles by Lars-Ivar Ringbom, Alvar Aalto, Sven Markelius, and C.-E. Olin.

67 Renja Suominen-Kokkonen, "The Silent Personage - the Architect Aino Marsio-Aalto," in Ulla Kinnunen (ed.), Aino Aalto, (Alvar Aalto Museum, 2004).

68 Kirsi Saarikangas, "Järkiperäinen ja tarkoituksenmukainen pohjaratkaisu," in Tuomi, Hilding Ekelund (1893-1984), 198-218.

$69 \quad$ Arkkitehti, no. 1 (1.1.1925): 6-13;

Rakennustaito, no. 16 (1937): 279-283. The latter journal published detailed model drawings of a kitchen that seems to have been greatly influenced by Schütte-Lihotzky.

70 The Martha Organization is a Finnish home economics organization, founded in 1899 to promote well-being and quality of life in the home. It carries out cultural and civic education and does advocacy work in Finland.

$71 \quad$ Arkkitehti, no. 8 (1.8.1928): 118-122.

$72 \quad$ Arkkitehti, no. 8 (1.8.1930); see also Hilding Ekelund, "Rakennustaide ja Rakennustoiminta 19181947," 120.

$73 \quad$ Arkkitehti, no. 1 (1.1.1931): 2.

$74 \quad$ Arkkitehti, no. 8 (1.8.1934): 117-118.

75 On Gropius' earlier standardization, when

Neufert was his assistant, see Atli M. Seelow, "The

Construction Kit and the Assembly Line-Walter

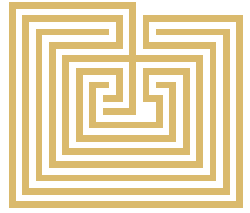


Gropius' Concepts for Rationalizing Architecture," Arts, 7, no. 4 (2018): 95. https://doi.org/10.3390/ arts7040095.

$76 \quad$ Arkkitehti, no. 5-6 (1.05.1944): 57-60. In this new review, Arkkitehti already mentions that the Finnish RT manual has copied parts of Neufert's manual. In English, for more on the relationship between Neufert and Aalto based on earlier research see Nader Vossoughian, "Alvar Aalto, Ernst Neufert, and Architectural Standardization in Germany and Finland, 1933-45," Journal of the Society of Architectural Historians 1 (June 2020); 79, no. 2: 202-212. A more profound study based on original material (unlike Vossoughian) on standardization and Puutalo Oy will soon be published by Laura Berger, Philip Tidwell, and Kristo Vesikansa: New Standards. Timber Houses Ltd. 1940-1955 (Garret Publications, 2021).

77 Rakennustaito, no. 22-23 (30.11.1944): 343-350.

78 Helsingin Sanomat, 30.1.1943: 3, 8 The same story was run in other major national newspapers with model plans for apartments and spreadsheets showing mass-produced housing standards.

79 On Asuntokiinteistö, see Suomen asuntokiinteistöliiton julkaisu, no. 11 (1.11.1938): 94 $80 \quad$ Arkkitehti, no. 10 (1.10.1939): 145-148. $81 \quad$ Arkkitehti, no. 7 (01.07.1933): 100-102. 82 Arkkitehti, no. 1 (1.1.1935): 3; Riitta Nikula "Rakennustaiteen 1920- ja 1930-luku," in Ars Suomen taide, Vol. 5, 98

$83 \quad$ Arkkitehti, no. 3 (1.3.1934): 35 84 As mentioned before, the architects developing and speculating with housing companies had a long history in Helsinki. The number of architects acting as the housing companies' founding shareholders form a rather long list: Ole Gripenberg, Sigurd Frosterus, Lars Sonck, Onni Tarjanne, Gustav Nyström, Usko Nyström, Toivo Päiviö, Viljo Revell, Heikki Riihimäki, Niilo Kokko, Arvo O. Aalto, and several others.

$85 \quad$ Arkkitehti, no. 2 (1.2.1933): 20-21

$86 \quad$ Arkkitehti, no. 7 (1.7.1934): 103

$87 \quad$ Arkkitehti, no. 2 (1.2.1931): 32.

$88 \quad$ Arkkitehti, no. 3 (1.3.1931): 21. Ekelund repeated his outcry with same words in Arkkitehti, no. 6 (1.6.1936): 81-82.

$89 \quad$ Niilo Kokko (1907-1975) was probably the most famous of the three. Together with Viljo Revell (1910-1964) and Heimo Riihimäki (1907-1962),

they won the design competition for the Lasipalats as students. All three became prominent housing architects, but especially Revell, who later achieved fame for designing the Toronto City Hall.

$90 \quad$ Birger Brunila, "Asemakaavoitus 19181945," in Helsingin kaupungin historia, Vol. 1, 55.

Tommi Lindh, Töölöläisfunktionalismin 4 vaihetta, 131

91 Arkkitehti, no. 5-6 (1.5.1939): 92-93.

$92 \quad$ Arkkitehti, no. 7 (1.7.1934): 94-95.

93 Arkkitehti, no. 6 (1.6.1932): 81-82

94 Helsingin Sanomat, no. 168, 23.06.1932, 9

95 Ilmari Niemeläinen (1910-1951) participated in the 1936 Berlin Olympics in diving, placing $13^{\text {th }}$ and $14^{\text {th }}$. During this trip, he also visited sites representative of modern German architecture. He was less successful in the 1948 London Olympics (placing $19^{\text {th }}$ ), but he received a bronze medal in urban design for his Kemi city master plan, when urban design was still a competitive sport. $96 \quad$ Arkkitehti, no. 8 (1.8.1934): 122. In the following issue (no. 9, 1934) of Arkkitehti, Ekelund himself "anonymously" condemned the flats for being too small and unsatisfactory.

97 Kiinteistökortisto: 344 Kiinteistökortisto, 11 kaupunginosa (Kallio), kortteli 324

98 HKRAVA 75-078676, 18.4.1934 (Helsinki,

building permission drawing database)

$99 \quad$ Arkkitehti, no. 4 (1.4.1931): 58-63.

$100 \quad$ Arkkitehti, no. 7 (1.7.1934): 96-100.

101 Domus 5 (1933): 130-132. Nils Gustav

Hahl (1904-1941) was an art historian and one of the original founders (together with the Aaltos, Maire Gullichsen, and others) of the furniture company Artek in 1935. He was also the last editor in chief of the Finnish journal Domus and had a wide international network of contacts, including several German contacts, and he surely knew exactly what the Bauhaus movement was when he compared it to Juslén's work. See: Pekka Suhonen, Artek (Artek, 1985).

102 Kalevi Saanilahti, Arkkitehdin kahleet vai ohjakset (Teknillisen korkeakoulun arkkitehtiosaston tutkimuksia, 1996/10); HKRAVA 75-033803 (Helsinki, building permission drawing database).

103 Arkkitehti, no. 7 (1.7.1943): 71-75; Hilding Ekelund, "Rakennustaide ja Rakennustoiminta 19181947," 127. Olli Pöyry (1912-1973) continued with an academic career, but he had also travelled widely in

Germany, the Netherlands, Denmark, and Sweden. 104 HKRAVA 76-025656, 76-025657 and 76-025662 (Helsinki, building permission drawing database).

$105 \quad$ Nils Erik Wickberg, Byggnadskonst i Finland (Söderströms, 1959), 86-89. Nils Erik Wickberg (1909-2002) was an architect, a professor of

architecture history and an editor in chief at Arkkitehti.

D.Sc. (Tech.), MSc (Arch.), MA Juhana Heikonen is a researcher in the SpaceLaw project at the University of Helsinki. Heikonen's primarily interest is housing.

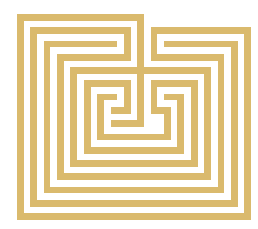

